\title{
Preconceptual design of the gas-phase decontamination demonstration cart
}

Dec 1993

Oak Ridge K-25 Site, TN (United States)

Reproduced and Distributed by:

U.S. DEPARTMENT OF ENERGY

Office of Scientific and Technical Information P.O. Box 62

Oak Ridge, TN 37831 


\section{DISCLAIMER}

This report was prepared as an account of work sponsored by an agency of the United States Government. Neither the United States Government nor any agency Thereof, nor any of their employees, makes any warranty, express or implied, or assumes any legal liability or responsibility for the accuracy, completeness, or usefulness of any information, apparatus, product, or process disclosed, or represents that its use would not infringe privately owned rights. Reference herein to any specific commercial product, process, or service by trade name, trademark, manufacturer, or otherwise does not necessarily constitute or imply its endorsement, recommendation, or favoring by the United States Government or any agency thereof. The views and opinions of authors expressed herein do not necessarily state or reflect those of the United States Government or any agency thereof. 


\section{DISCLAIMER}

Portions of this document may be illegible in electronic image products. Images are produced from the best available original document. 
K/TCD-1076

\title{
PRECONCEPTUAL DESIGN OF THE GAS-PHASE DECONTAMINATION DEMONSTRATION CART
}

\author{
E. B. Munday
}

Environmental and Chemical Technology Department Applications and Development Section Technical Division

December 1993

Prepared by the

OAK RIDGE K-25 SITE

Oak Ridge, Tennessee 37831-7387 managed by

MARTIN MARIETTA ENERGY SYSTEMS, INC.

for the

U. S. DEPARTMENT OF ENERGY

under contract DE-AC05-84OR21400 


\section{CONTENTS}

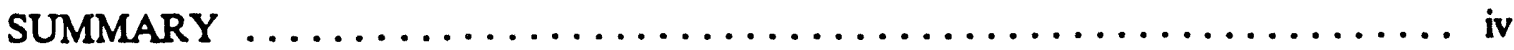

1. INTRODUCTION $\ldots \ldots \ldots \ldots \ldots \ldots \ldots \ldots \ldots \ldots \ldots \ldots \ldots \ldots \ldots \ldots \ldots$

2. REACTION CHEMISTRY FOR THE FULL-SCALE DESIGN $\ldots \ldots \ldots \ldots, 2$

1.1 MAIN REACTION OF CHLORINE TRIFLUORIDE WITH

URANIUM DEPOSITS ....................... 2

1.2 CHEMICAL TRAPPING OF URANIUM HEXAFLUORIDE

WITH SODIUM FLUORIDE TRAPS $\ldots \ldots \ldots \ldots \ldots \ldots \ldots \ldots, 3$

1.3 OFF-GAS TREATMENT WTTH A KOH SCRUBBER $\ldots \ldots \ldots \ldots \ldots 4$

3. PROCESS STEPS $\ldots \ldots \ldots \ldots \ldots \ldots \ldots \ldots \ldots \ldots \ldots \ldots \ldots \ldots \ldots \ldots$

4. CART DESCRIPTION AND OPERATION $\ldots \ldots \ldots \ldots \ldots \ldots \ldots \ldots, 10$

4.1 EQUIPMENT FEATURES SUMMARY $\ldots \ldots \ldots \ldots \ldots \ldots \ldots \ldots, 10$

4.2 MATERIAL BALANCE SUMMARY $\ldots \ldots \ldots \ldots \ldots \ldots \ldots \ldots, 11$

4.3 EQUIPMENT OPERATION $\ldots \ldots \ldots \ldots \ldots \ldots \ldots \ldots \ldots \ldots, 12$

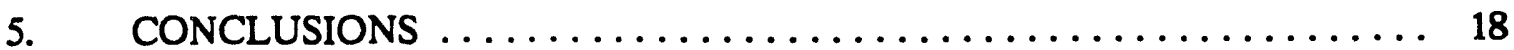

6. REFERENCES $\ldots \ldots \ldots \ldots \ldots \ldots \ldots \ldots \ldots \ldots \ldots \ldots \ldots \ldots \ldots \ldots$

Appendix A

COST ESTIMATE FOR DISPOSAL OF CHLORINE TRIFLUORIDE IN A POTASSIUM HYDROXIDE SCRUBBER ........... A-1

Appendix B

GAS-PHASE DESIGN INFORMATION $\ldots \ldots \ldots \ldots \ldots \ldots \ldots \ldots$ B-1

Appendix C

PROCESS FLOW DIAGRAMS $\ldots \ldots \ldots \ldots \ldots \ldots \ldots \ldots \ldots, \mathrm{C}-1$ 


\section{SUMMARY}

Removal of uranium deposits from the interior surfaces of gaseous diffusion equipment will be a major portion of the overall multibillion dollar effort to decontaminate and decommission the gaseous diffusion plants. Long-term low-temperature (LTLT) gas-phase decontamination is being developed at the K-25 Site as an in situ decontamination process that is expected to significantly lower the decontamination costs, reduce worker exposure to radioactive materials, and reduce safeguard concerns. The process steps for the LTLT method are outlined briefly as follows.

1. Seal, evacuate, and leak test the item of gaseous diffusion equipment to be decontaminated.

2. Evacuate the item requiring decontamination to -0.02 psia in preparation for pretreatment.

3. Pretreat the item by adding a small amount of chlorine trifluoride $\left(\mathrm{ClF}_{3}\right)$ gas to remove residual water, highly reactive organics, or highly reactive deposits.

4. Analyze the pretreatment gases for hydrogen fluoride (HF).

5. Evacuate and dispose of the pretreatment gases, if necessary based on the gas analysis.

6. Repeat steps 3-5, as necessary, to complete removal of residual water, organics, and highly reactive deposits.

7. Slowly add $\mathrm{ClF}_{3}$ to $\sim 4.0$ psia.

8. Periodically analyze gas samples and monitor the system pressure while the $\mathrm{CIF}_{3}$ slowly reacts with the uranium deposits within the item being decontaminated for an extended time (possibly months).

9. Recover the uranium hexafluoride $\left(\mathrm{UF}_{6}\right)$ from the process gases by use of sodium fluoride (NaF) traps.

10. Evacuate and dispose of the remaining process gases.

Since the demonstration is experimental in nature, more analysis and monitoring of the process gases will be done than vould be the case for a production phase. Although a lengthy period is involved for the reaction of $\mathrm{ClF}_{3}$ and the uranium deposits, little operator time is required since the $\mathrm{ClF}_{3}$ is sealed at subatmospheric pressure at $\sim 75^{\circ} \mathrm{F}$ within the item requiring decontamination. Over $90 \%$ of the uranium present was often removed during lab experiments after several days exposure, but uranium removal to decontamination levels required considerably longer time.

This report documents the preconceptual design of the process equipment that is necessary to conduct a full-scale demonstration of the LTLT method in accordance with the process steps listed above. The process equipment and method proposed in this report are not intended to represent a full-scale production campaign design and operation, since the gas evacuation, gas charging, and off-gas handling systems that would be cost effective in a production campaign are not cost effective for a first-time demonstration. However, the design presented here is expected to be applicable to special decontamination projects beyond the demonstration, which could include the Deposit Recovery Program. The equipment will therefore be sized to a $200 \mathrm{ft}^{3}$ size 1 converter (plus a substantial conservative design margin), which is the largest item of interest for gas phase decontamination in the Deposit Recovery Program. 
The decontamination equipment will allow recovery of the $\mathrm{UF}_{6}$, which is generated from the reaction of $\mathrm{ClF}_{3}$ with the uranium deposits, by use of $\mathrm{NaF}$ traps. Two sets of NaF traps will be used: one set maintained at $200^{\circ} \mathrm{F}$ to selectively trap $\mathrm{UF}_{6}$ followed by a set maintained at ambient temperature to selectively trap $\mathrm{HF}$ and residual amounts of $\mathrm{UF}_{6}$. The other off-gases pass through the traps unaffected by the $\mathrm{NaF}$. The $\mathrm{UF}_{6}$ can be transferred from the $\mathrm{NaF}$ traps into a $\mathrm{UF}_{6}$ cylinder in a cold bath by heating the $\mathrm{NaF}$ traps to $700^{\circ} \mathrm{F}$ and then purging the $U_{F_{6}}$ from the $N a F$ traps into the $U F_{6}$ cylinder using a low flow rate stream of nitrogen $\left(\mathrm{N}_{2}\right)$ and fluorine $\left(\mathrm{F}_{2}\right)$.

The NaF traps can be operated in a closed loop, recirculating arrangement that will allow the process gases to flow from the item being decontaminated to the NaF traps for selective recovery of the $\mathrm{UF}_{6}$ and $\mathrm{HF}$ without removal of the $\mathrm{CIF}_{3}$ and then back to the item being decontaminated. This feature allows the $\mathrm{UF}_{6}$ concentration to be reduced greatly in a manner that is verifiable with a gas analyzer prior to pumping the off-gases into a large volume, evacuated, portable tank. This may allow the process point for NESHAP air permits to be taken as the recirculating loop, which contains greatly reduced amounts of $\mathrm{UF}_{6}$ as compared to the item being decontaminated, that would otherwise be taken as the process point. When processing items that contain unusually heavy uranium deposits, the recirculating loop can be used to remove $\mathrm{UF}_{6}$ and $\mathrm{HF}$ and add make-up $\mathrm{CIF}_{3}$.

After removal of the $\mathrm{UF}_{6}$ and $\mathrm{HF}$ in the $\mathrm{NaF}$ traps, the off-gases (excess $\mathrm{ClF}_{3}, \mathrm{ClF}, \mathrm{ClO}_{2} \mathrm{~F}$, etc.) will be pumped into the previously evacuated portable tank. The tank will be taken to a potassium hydroxide $(\mathrm{KOH})$ scrubber that is located near a permitted stack. The gases will be pumped from the tank into the scrubber for removal of the chlorine and fluorine constituents of the off-gases, and the cleansed off-gases will be vented out the stack. The entire gas-phase decontamination process will be conducted at subatmospheric pressure. 


\section{INTRODUCTION}

Decontamination of the five gaseous diffusion process buildings at the K-25 Site will be a multibillion dollar project that will also present new challenges from the standpoint of health physics, industrial hygiene, waste generation, and environmental concerns. In situ LTLT gasphase decontamination is being developed as a technology that has the potential to substantially lower the decontamination costs while reducing worker exposure to hazardous and radioactive materials and also reduce criticality and safeguard concerns.

The objective of gas-phase decontamination is to use $\mathrm{ClF}_{3}$ gas to fluorinate nonvolatile uranium deposits to form volatile $\mathrm{UF}_{6}$, which can be recovered by chemical trapping. The LTLT process permits the removal of uranium from the inside of gas-tight gaseous diffusion process equipment at room temperature by long-term exposure to $\mathrm{ClF}_{3}$ at subatmospheric pressure. Although the exposure time for decontamination of the uranium maybe $>2$ months, little operator time is envisioned since few actions are required of an operator during the reaction period. Report K/TCD-1048, Feasibility of Gas-Phase Decontamination of Gaseous Diffusion Equipment ${ }^{1}$ was issued in March, 1993 to document recent laboratory experiments that support the feasibility of the process. Since the samples evaluated in K/TCD-1048 were all obtained from a section of copper seal-exhaust tube from the K-33 cascade, the report recommended that additional experiments be performed on additional samples of different metals found in a cascade. These experiments are continuing at present. The report also recommended that a full-scale demonstration of the process be performed on gaseous diffusion equipment. Although the reaction time required for complete decontamination of metal surfaces can be lengthy, the laboratory experiments indicate that $>90 \%$ of uranium deposits are removed after only several day which strongly suggests that the method may also be very useful for deposit reduction activities to reduce criticality concerns.

The purpose of the present report is to document the development of the preconceptual design of equipment for a full-scale demonstration of this concept for gas-phase decontamination. The engineering design can be expected to recommend modifications to this basic design, as well as develop engineering drawings for construction of the equipment. The equipment being designed for the full-scale demonstration may also serve a very practical application in the Deposit Recovery Program, which will remove enriched uranium deposits from locations in the K-25 building. For this reason, the equipment will be sized with a substantial contingency factor to allow decontamination of a size 1 converter or smaller items of gaseous diffusion equipment. The design uses critically safe 5-inch geometry where necessary to accommodate the HEU deposits.

Since the equipment and process described in this report serve principally to demonstrate the method on individual pieces of gaseous diffusion equipment in an experimental mode of operation as opposed to a production mode of operation, the design and process are not intended to represent the most economical arrangement for conducting a full-scale production campaign. For example, the present design proposes to use a $\mathrm{KOH}$ scrubber for disposal of the excess $\mathrm{ClF}_{3}$ at the conclusion of the process. An important objective prior to a production campaign would be development of a method to recycle excess $\mathrm{ClF}_{3}$ and regenerate $\mathrm{ClF}_{3}$ from the chlorine bearing off-gases formed from the reaction of $\mathrm{ClF}_{3}$ and the uranium deposits. Regeneration of $\mathrm{ClF}_{3}$ by means of a catalyzed fluorine reaction is a possibility that warrants future investigation. The recycle and regeneration of $\mathrm{ClF}_{3}$ would save the expense of $\mathrm{ClF}_{3}$, but more importantly, hazardous gaseous effluents would be almost eliminated. $\mathrm{KOH}$ scrubber solution would also be minimized. 


\section{REACTION CHEMISTRY FOR THE FULLSCALE DESIGN}

\subsection{MAIN REACTION OF CHLORINE TRIFLUORIDE WITH URANIUM DEPOSITS}

Although several uranium compounds are possible within the gaseous diffusion equipment including uranium tetrafluoride $\left(\mathrm{UF}_{4}\right)$, uranium pentafluoride $\left(\mathrm{UF}_{5}\right)$, and possibly other uranium oxyflourides, the principle compound expected is uranyl fluoride $\left(\mathrm{UO}_{2} \mathrm{~F}_{2}\right)$. Shrewsberry and Williamson ${ }^{2}$ report the following reaction between $\mathrm{UO}_{2} \mathrm{~F}_{2}$ and $\mathrm{ClF}_{3}$.

$$
\begin{aligned}
& \mathrm{UO}_{2} \mathrm{~F}_{2}+2 \mathrm{ClF}_{3}-\mathrm{ClO}_{2} \mathrm{~F}+\mathrm{ClF}+\mathrm{UF}_{6} \\
& \mathrm{ClO}_{2} \mathrm{~F}-\mathrm{ClF}+\mathrm{O}_{2} \\
& 4 \mathrm{ClF}+\mathrm{UO}_{2} \mathrm{~F}_{2}-\mathrm{O}_{2}+2 \mathrm{Cl}_{2}+\mathrm{UF}_{6}
\end{aligned}
$$

(main reaction)

(partial secondary reaction)

(partial secondary reaction)

At room temperature, reactions (2) and (3) apparently do not proceed very far even after long exposure time as long as excess $\mathrm{ClF}_{3}$ is present; therefore, equation 1 will be accepted as a representation of the reaction equation. (If the $\mathrm{ClF}_{3}$ is depleted, reaction (3) apparently occurs even at room temperatire). An adjustment to equation 1 is needed for water of hydration, which is likely to be present but which is not included in equation 1 . The amount of hydration is variable in the cascade equipment. $\mathrm{UO}_{2} \mathrm{~F}_{2}$ samples that were removed from a K-33 cascade at the K-25 site were estimated by $\mathrm{x}$-ray diffraction to have a hydrated formula of $\mathrm{UO}_{2} \mathrm{~F}_{2} \bullet 1.6 \mathrm{H}_{2} \mathrm{O}$, but the reaction products formed following exposure of $\mathrm{ClF}_{3}$ to similar samples indicated lower amounts of hydration were present. A hydrated formula of $\mathrm{UO}_{2} \mathrm{~F}_{2}$ - $\mathrm{H}_{2} \mathrm{O}$ will be assumed. The following reaction of $\mathrm{ClF}_{3}$ and water was given by Cooper, Dost, and Wang ${ }^{3}$.

$$
\mathrm{ClF}_{3}+\mathrm{H}_{2} \mathrm{O}-2 \mathrm{HF}+0.5 \mathrm{ClO}_{2} \mathrm{~F}+0.5 \mathrm{ClF}
$$

Combining equation 1 and 4 results in the following equation, which will serve as an approximation for the reaction of $\mathrm{ClF}_{3}$ with the cascade uranium deposits.

$$
3 \mathrm{ClF}_{3}+\mathrm{UO}_{2} \mathrm{~F}_{2} \cdot \mathrm{H}_{2} \mathrm{O}-1.5 \mathrm{ClO}_{2} \mathrm{~F}+1.5 \mathrm{ClF}+\mathrm{UF}_{6}+2 \mathrm{HF}
$$

If the $\mathrm{ClF}_{3}$ concentration is depleted and if moisture is present, chlorine dioxide $\left(\mathrm{ClO}_{2}\right)$ and perhaps other chlorine oxyfluorides can be formed that could pose explosion hazards if handled improperly. For example, $\mathrm{ClO}_{2}$ has been known to condense and concentrate to dangerous levels in cold traps that exploded when the traps were heated. To guard against this possibility, $\mathrm{NaF}$ traps will be used to trap the $\mathrm{UF}_{6}$ regenerated from the $\mathrm{ClF}_{3}-\mathrm{UO}_{2} \mathrm{~F}_{2}$ reaction rather than collecting the $\mathrm{UF}_{6}$ directly in cold traps. $\mathrm{ClF}_{3}$ has been safely used at the 
gaseous diffusion plants for decades for applications similar to this project. R. L. Farrar and E. J. Barber have written reports on the safe handling of $\mathrm{ClF}_{3}$ and chlorine oxides and oxyfluorides. ${ }^{4,5}$

\subsection{CHEMICAL TRAPPING OF URANIUM HEXAFLUORIDE WITH SODIUM FLUORIDE TRAPS}

Sodium fluoride (NaF) traps have been used for many years at the DOE gaseous diffusion plants to selectively remove $\mathrm{UF}_{6}$ from gas streams and to subsequently recover the $\mathrm{UF}_{6}$ from the $\mathrm{NaF}$ traps. $\mathrm{Katz}^{6}$ reports that the removal of $\mathrm{UF}_{6}$ from a gas stream is accomplished by formation of the following complex:

$$
2 \mathrm{NaF}+\mathrm{UF}_{6}-\mathrm{UF}_{6} \bullet 2 \mathrm{NaF} \Delta \mathrm{H}=-19.1 \mathrm{kcal} / \mathrm{mol}
$$

which is reversed at higher temperatures. Equation 6 is known to be an over simplification, but this equation is useful for modeling purposes. Katz determined that at room temperature, $\mathrm{NaF}$ is capable of reducing the vapor pressure of $\mathrm{UF}_{6}$ to $\sim 1.5 \times 10^{-5}$ torr $\mathrm{UF}_{6}$. The equation which describes the variation of $\mathrm{UF}_{6}$ vapor pressure over $\mathrm{NaF}$ at various temperatures is given by

$$
\begin{aligned}
& \log _{10} P=9.25-4180 / T_{k}, \\
& \text { where } P=\text { dissociation pressure, } \mathrm{mmHg} \text { and } \\
& T_{k}=\text { temperature, }{ }^{\circ} \mathrm{K} .
\end{aligned}
$$

This very low $\mathrm{UF}_{6}$ pressure over NaF could result in $<1.0 \mathrm{ppm}$ levels of $\mathrm{UF}_{6}$ in the gas stream exiting a $\mathrm{NaF}$ trap. In practice, the $\mathrm{UF}_{6}$ level has been reduced to $<20 \mathrm{ppm}$ at a trap outlet when the inlet concentration was as high as $4.4 \% \mathrm{UF}_{6}$ by volume. ${ }^{7} \mathrm{HF}$ will also be trapped by $\mathrm{NaF}$, especially if the traps are maintained near room temperature. Increasing the $\mathrm{NaF}$ trap temperature to $-200^{\circ} \mathrm{F}$ allows most $\mathrm{UF}_{6}$ to be trapped while most HF passes through. Fluorinating gases such as $\mathrm{F}_{2}$ and $\mathrm{ClF}_{3}$ do not complex with $\mathrm{NaF}$ and do not influence the ability of $\mathrm{NaF}$ to complex $\mathrm{UF}_{6}$ even at a high concentration of fluorinating gases. ${ }^{8}$ Theoretically, NaF could trap an amount of $\mathrm{UF}_{6}>4$ times the weight of the NaF, but in laboratory experiments with new NaF the figure is $\sim 0.8$ times. For trap design that will involve regeneration of the $\mathrm{NaF}$, a loading ratio of $0.25 \mathrm{UF}_{6}$ to $\mathrm{NaF}$ by weight is recommended, since the loading effectiveness slowly decreases as the $\mathrm{NaF}$ is regenerated numerous times. ${ }^{8}$ The recommended superficial face velocity for gases flowing through $\mathrm{NaF}$ traps is $1.0 \mathrm{ft} / \mathrm{s}^{8,9}$

The $\mathrm{UF}_{6}$ can be recovered off the $\mathrm{NaF}$, thereby regenerating the $\mathrm{NaF}$ for reuse, by heating the trap to $\sim 700^{\circ} \mathrm{F}$ and purging the $\mathrm{UF}_{6}$ from the trap with $\mathrm{N}_{2}$. A small concentration of $\mathrm{F}_{2}$ ( $\sim 3 \% \mathrm{vol}$ ) is added to the $\mathrm{N}_{2}$ to prevent the formation of $\mathrm{UF}_{5}$ on the $\mathrm{NaF}^{10} \mathrm{UF}_{5}$ has a low melting point which will result in fusing the pellets causing decreased trapping efficiency. The $\mathrm{N}_{2} / \mathrm{F}_{2}$ mixture is flowed through the traps opposite the usual direction of gas flow during the trapping operation. The flow should be started prior to beginning to heat the trap. ${ }^{11}$ The superficial velocity of the gases through the trap during regeneration should be much slower 
( $\sim 0.1 \mathrm{ft} / \mathrm{s}$ ) than during $\mathrm{UF}_{6}$ loading. According to trapping facility operating experience at the Paducah Gaseous Diffusion Plant (PGDP), the regeneration is complete when the $\mathrm{UF}_{6}$ concentration at the trap outlet falls to $0.1 \% .^{11}$

The NaF pellets slowly deteriorate with each loading-regeneration cycle. They will remain effective longer if they are regenerated shortly after $\mathrm{UF}_{6}$ begins to penetrate the trap due to nearly full $\mathrm{UF}_{6}$ loading. ${ }^{10}$ In practice at the PGDP, the pellets are regenerated and reused until the pellet deterioration results in an unacceptably high pressure drop across the traps during gas flow through the traps under normal operating conditions. ${ }^{11}$

\subsection{OFF-GAS TREATMENT WITH A KOH SCRUBBER}

Initially, consideration was given to treating the off-gases by flowing them through chemical traps containing alumina pellets. The alumina will remove the fluorine constituent of $\mathrm{ClF}_{3}$, $\mathrm{ClF}$, and $\mathrm{ClO}_{2} \mathrm{~F}$ very effectively. Also, alumina pellets avoid the solution preparation, neutralization, and filtration operations that are often associated with an aqueous $\mathrm{KOH}$ scrubber system. However, the alumina has a considerable disadvantage compared to a KOH scrubber because the alumina converts the chlorine constituent of the off-gases to chlorine $\left(\mathrm{Cl}_{2}\right)$ gas. Stack modeling by the Environmental Management Department at the K-25 Site indicated that unacceptably high concentrations of $\mathrm{Cl}_{2}$ gas would result from the off-gases if alumina traps were used. For this reason, the use of alumina traps was abandoned, and the use of a KOH scrubber has been substituted.

The $\mathrm{KOH}$ scrubber solution is typically $20 \% \mathrm{KOH}$ in water solution initially. Different scrubber designs are possible. Previously at the K-25 Site, the scrubber consisted of a tunnel with banks of spray nozzles that sprayed the $\mathrm{KOH}$ solution in the opposite direction of gas flow through the tunnel. A countercurrent flow packed tower might also be used, but the gas pressure drop through the tower will be greater than that resulting from use of the spray tunnel. The use of a packed tower scrubber could complicate nuclear criticality concerns unless the packed tower has a critically safe geometry. The $\mathrm{KOH}$ reacts with the chlorine and fluorine constituents of the off-gases to form potassium fluoride (KF) and potassium chloride $(\mathrm{KCl})$. The exact equation for the reaction is in question because the reaction may vary depending upon the concentration of the $\mathrm{KOH}$ solution and depending upon the concentration of the $\mathrm{ClF}_{3}$ gas entering the scrubber. The following equation ${ }^{12}$ is considered a reasonable representation of the reaction for design purposes.

$$
\mathrm{ClF}_{3}+4 \mathrm{KOH}-1 / 3 \mathrm{KCl}+2 / 3 \mathrm{KClO}_{3}+3 \mathrm{KF}+2 \mathrm{H}_{2} \mathrm{O}
$$

Since the potassium chlorate $\left(\mathrm{KClO}_{3}\right)$ formed during the reaction is a strong oxidizer, the scrubber solution or scrubber solution precipitate should not be dried in the presence of an organic or combustible material. The $\mathrm{KClO}_{3}$ concentration formed during reaction of $\mathrm{ClF}_{3}$ and $\mathrm{KOH}$ solution can be minimized by keeping the $\mathrm{ClF}_{3}$ gas concentration at the inlet to the scrubber at less than $5 \% .^{13}$

A KOH scrubber was successfully used at the Oak Ridge Gaseous Diffusion Plant for removal of $\mathrm{ClF}_{3}, \mathrm{~F}_{2}$, and residual $\mathrm{UF}_{6}$ from cascade off-gases. The reported ${ }^{14}$ efficiencies for removal of the fluorine, chlorine, and uranium constituents from these compounds were $99 \%$, $98 \%$, and $82 \%$ respectively based on the mass of the element entering the scrubber per month compared to the mass of the element leaving the scrubber per month. The possible 
formation of potentially hazardous gaseous chlorine oxides, especially $\mathrm{ClO}_{2}$ can be avoided by ensuring that the scrubber solution remains a basic solution, i.e. the $\mathrm{KOH}$ must not be allowed to be depleted during reaction with $\mathrm{ClF}_{3}$. The $\mathrm{KOH}$ scrubber solution can be regenerated several times by addition of calcium hydroxide $\mathrm{Ca}(\mathrm{OH})_{2}$ to the depleted solution. The $\mathrm{Ca}(\mathrm{OH})_{2}$ reacts with $\mathrm{KF}$ according to the following reaction to regenerate $\mathrm{KOH} .{ }^{15}$

$$
\left.\left.\mathrm{Ca}(\mathrm{OH})_{2}(\text { solid })+2 \mathrm{KF} \text { (soluble }\right)-\mathrm{CaF} \text { (insoluble }\right)+2 \mathrm{KOH} \text { (soluble) }
$$

Since the $\mathrm{Ca}(\mathrm{OH})_{2}$ regenerates the $\mathrm{KF}$ to $\mathrm{KOH}$ but does not regenerate the $\mathrm{KCl}$, the scrubber solution will accumulate $\mathrm{KCl}$ and eventually require replacement. During the demonstration phase, the volume of $\mathrm{CF}_{3}$ disposed will probably be too small to warrant this regeneration step. The spent scrubber solutions will likely be disposed in the Central Neutralization Facility located at the K-25 Site.

Waste $\mathrm{KOH}$ solution was previously processed at the K-25 Site by neutralizing the solution with $\mathrm{HCl}$ and adding $\mathrm{CaCl}_{2}$ to precipitate out $\mathrm{CaF}_{2}$. The process is illustrated in Figure 1. The cost to dispose of one pound of $\mathrm{ClF}_{3}$ in a $\mathrm{KOH}$ scrubber is roughly estimated ${ }^{16}$ in Appendix $A$ at $\$ 11.77 / \mathrm{hb}$. Since the process will likely require modification to meet recent environmental standards, these costs will most likely increase above this estimate. 


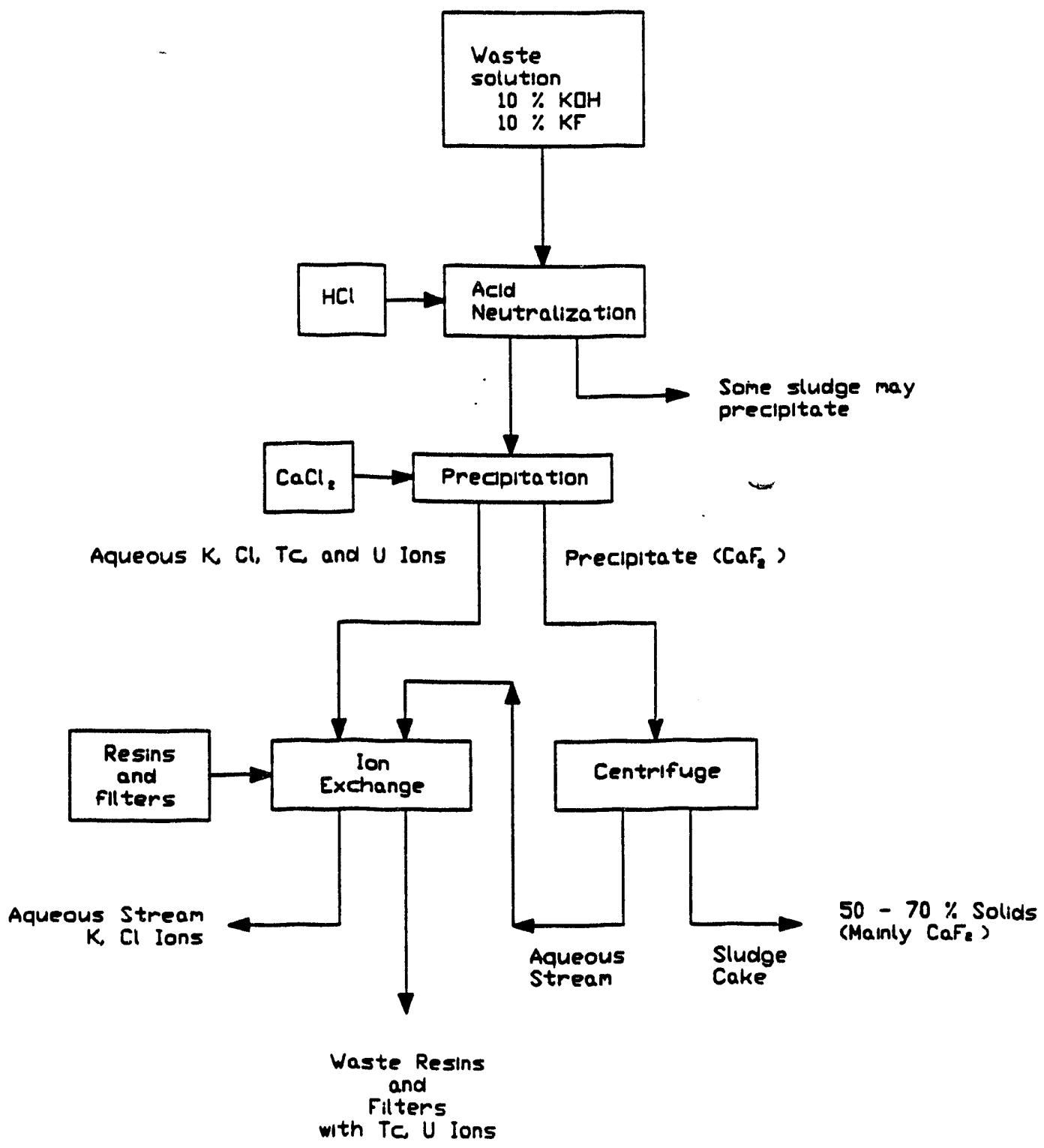

Fig. 1. Schematic of a waste $\mathrm{KOH}$ solution treatment. 


\section{PROCESS STEPS}

The process step descriptions are not intended to provide operating details but rather to roughly describe the basic objectives that the equipment design must meet. The design of the equipment that will meet these objectives is discussed in the next section. The process steps for the demonstration of the full-scale gas-phase decontamination equipment are outlined below and are described in more detail in the narrative.

1. Sealing, evacuation, and leak testing of the item requiring decontamination.

2. Evacuation of the item requiring decontamination to $\sim 0.02$ psia in preparation for pretreatment.

3. Pretreatment with a small amount of $\mathrm{ClF}_{3}(\sim 0.25$ psia $)$ to remove water, highly reactive organics, or highly reactive deposits.

4. Analysis of pretreatment gas for hydrogen fluoride (HF).

5. Evacuation and disposal of pretreatment gases, if necessary.

6. Repeat steps 3-5, as necessary, to remove water, organics, and highly reactive deposits.

7. Slow addition of $100 \% \mathrm{ClF}_{3}$ to $\sim 4.0$ psia.

8. Periodic analysis of gas samples while the reaction proceeds for an extended time (possible months).

9. Recovery of $\mathrm{UF}_{6}$ by use of NaF traps.

10. Evacuation and disposal of the fluorinating off-gases.

11. Regeneration of the $\mathrm{UF}_{6}$ from the $\mathrm{NaF}$ traps and recovery of the $\mathrm{UF}_{6}$ into standard $5 \mathrm{~A}$ or $5 \mathrm{~B}$ shipping cylinders.

The item requiring decontamination must be rendered leak tight and be leak tested prior to gas-phase decontamination. For the purposes of the full-scale demonstration, the items to be decontaminated (compressor, converter, etc.) will be isolated from the other gaseous diffusion equipment. During a decontamination production campaign, the items requiring decontamination might be left joined together in the cascade cells and an entire cell decontaminated at once. Flanges and small valves will be installed on the item to be decontaminated. The item will be evacuated to determine whether it is leak tight. If not, it will be sealed at all likely leak sites and rechecked. Since the air initially present in the item of gaseous diffusion equipment to be decontaminated may still contain small amounts of $\mathrm{UF}_{6}$ or HF, the air cannot be pumped out into the building unless the Industrial Hygiene Department approves the concept of puniping the air through an alumina trap to remove the residual $\mathrm{UF}_{6}$ and $\mathrm{HF}$ prior to release to the building interior. If necessary, the air will be evacuated into the same portable tank that will be used to transfer the off-gases to a $\mathrm{KOH}$ scrubber (see next section). The leak hunting and sealing process will continue until the item is gas tight. For a centrifugal compressor, the most obvious leak point is the compressor seal. This leak point will be sealed by use of a Dresser coupling (UCCND Drawing E-PME-13053A598). Numerous methods are available for leak detection as reviewed in a report by Munday. ${ }^{17}$ A helium leak detector may prove best for detection of small leaks into the equipment following evacuation of air from the equipment. As a final check of system integrity prior to processing, the system will be evacuated to the desired pressure, and then it will be isolated for an appropriate time to monitor the rate of rise. 
Following successful leak testing, the item to be decontaminated will be evacuated to $\sim 0.02$ psia and then pretreated by slowly administering $100 \% \mathrm{ClF}_{3}$ gas to a pressure of about 0.25 psia while monitoring for pressure excursions, which would indicate a rapid reaction. Calculations show that if a hypothetical instantaneous reaction occurred between the amount of $\mathrm{ClF}_{3}$ in a vessel at 0.25 psia partial pressure of $\mathrm{ClF}_{3}$ and water vapor, the resulting pressure in the vessel would still be less than one atmosphere. The surface of the item will be monitored with an infrared pyrometer to check for hot spots. The gas samples will also be analyzed with a Fourier Transform Infrared Spectrometer (FTIR) for HF, which is a reaction product of $\mathrm{ClF}_{3}$ with either water or organic material.

If the FTIR indicates that a large amount of HF has formed, the gases will be evacuated through the $\mathrm{NaF}$ chemical traps, and the decontamination item will be reevacuated to -0.02 psia. $\mathrm{ClF}_{3}$ will then be added again to increase the pressure to about 0.25 psia. Pretreatment will be continued until the amount of HF observed is low (the acceptable concentration of HF will be specified later). The amount of $\mathrm{ClF}_{3}$ will then be slowly increased while watching for pressure or temperature excursions and while also continuing to watch for sudden increases in $\mathrm{HF}$ concentration. $\mathrm{ClF}_{3}$ will be added until a pressure of $\sim 4$ psia of pure $\mathrm{ClF}_{3}$ is reached. The pressure of $\mathrm{ClF}_{3}$ charged to small volume items may be greater than 4 psia to increase the amount of $\mathrm{ClF}_{3}$ available for reaction.

Previous full-scale studies in heated furnace stands and recent laboratory data indicate that rapid reactions that would cause sudden pressure or temperature excursions are not to be expected. The pretreatment with $\mathrm{ClF}_{3}$ at 0.25 psia and gradual increase in $\mathrm{ClF}_{3}$ pressure to 4 psia mentioned above is intended to greatly mitigate the possibility of such a reaction even further. In the unlikely event that a rapid reaction is detected, the gases will be pumped from the item being decontaminated into a large evacuated tank described later in this report.

After charging the item to be decontaminated to 4 psia with $\mathrm{ClF}_{3}$, the charge of $\mathrm{ClF}_{3}$ will remain in the item for an extended time (possibly two or three months) without circulation of the gases. During this time, the pressure and temperature will be monitored, and gas samples will be occasionally analyzed to monitor reaction progress. Present plans are to design the decontamination equipment for remote operation to allow most activities (e.g. valve operations and FTIR gas analysis) to be performed from outside the radiation area. Although the process time may be lengthy for the LTLT method, the operator time during a production mode is expected to be short since operations are required only for a relatively short period during the total process time for any one item being decontaminated. An estimate of the amount of uranium initially present in the item to be decontaminated will be available from the gamma spectroscopic survey of the item. Gamma spectroscopy can also be used for a rough estimate of the uranium removal as the reaction progresses. The generation of $U_{6} F_{6}$ in the gas will provide the best means for monitoring the reaction progress.

Since the demonstration is an experimental mode of operation, the gas-phase decontamination equipment will remain connected to the item being decontaminated the entire process time, and the process will be monitored and analyzed much more closely than would be the case in a more production oriented mode. In a production mode, the item being decontaminated would be processed through the steps up to and including charging the item with $\mathrm{ClF}_{3}$. Then the item being decontaminated would be valved off from the decontamination process equipment, and the process equipment would be moved to another location to charge other items requiring decontamination with $\mathrm{ClF}_{3}$ until time to remove the gases from the first item charged with $\mathrm{ClF}_{3}$. The process equipment would then be reconnected to the first item to complete the recovery of the $U_{6}$ and the removal of the fluorinating gases. The process of purging and evacuating the off-gases from the item following decontamination is described in detail in the next section. 
The process equipment has the ability to flow the process gases in a recirculating loop from the decontaminated item, through the $\mathrm{NaF}$ traps for $\mathrm{UF}_{6}$ recovery and removal of $\mathrm{HF}$, and back to the decontamination item. This feature, which is further described in the next section, is needed for the following reasons. (1) The recirculating loop allows assurance that the UFF has been removed to low concentrations prior to pumping the off-gases into the portable tank, since gas analyzer capability within the recirculating loop allows a confirmation of low $\mathrm{UF}_{6}$ levels prior to evacuating the gases. If the gas analysis indicates that the $\mathrm{UF}_{6}$ concentration is above a certaia threshold, (i.e., $30 \mathrm{ppm}$ ), corrective action, such as slowing the gas flow rate through the $\mathrm{NaF}$ traps could be taken to further reduce the $\mathrm{UF}_{6}$ concentration in the gases exiting the $\mathrm{NaF}$ traps. If a recirculating loop were not used, an excessive amount of $\mathrm{UF}_{6}$ in the gas stream would not be detected on the analyzer before some of the $U_{F_{6}}$ is pumped to the tank with other gases. (2) The recirculating loop may simplify a NESHAP air permit request since the process point may be taken as the recirculating loop with a guaranteed low concentration of $\mathrm{UF}_{6}$ rather than taking the process point as the itern being decontaminated, which would contain a high concentration of UF 6 . (3) Some items requiring decontamination will have usually heavy uranium deposits which may significantly deplete the $\mathrm{ClF}_{3}$ and raise the $\mathrm{UF}_{6}$ and $\mathrm{HF}$ concentrations to high enough levels that they act a diluents, thus greatly slowing the reaction. In such cases, removing the $\mathrm{UF}_{6}$ and $\mathrm{HF}$ without removing the remaining $\mathrm{ClF}_{3}$ is very desirable from the standpoint of restoring the reaction rate and from the standpoint of removing the $U F_{6}$ to preclude possible desublimation of the $U_{F_{6}}$ on the walls of the vessel. (The partial pressure of $\mathrm{UF}_{6}$ would have to reach $1.1 \mathrm{psia}$ at $60^{\circ} \mathrm{F}$ before desublimation could occur). The recirculating loop will serve this purpose. Afte: removing the $\mathrm{UF}_{6}$ and $\mathrm{HF}$ present, additional $\mathrm{ClF}_{3}$ could be added to make up the amount depleted. (4) The same reasons given in (1) above may also allow nuclear criticality requirements on the portable tank and $\mathrm{KOH}$ scrubber to be relaxed since the $\mathrm{UF}_{6}$ concentrations can be guaranteed at low levels prior to pumping the gases into the tank.

All gases other than $\mathrm{UF}_{6}$ and $\mathrm{HF}$ will pass through the NaF traps unaffected. The other gases will be pumped into the portable tank and later pumped from the tank through the $\mathrm{KOH}$ scrubber for removal of the chlorine and fluorine constituents of the gases prior to venting the effluent to the stack. 


\section{CART DESCRIPTION AND OPERATION}

\subsection{EQUIPMENT FEATURES SUMMARY}

The cart design must allow the process steps described earlier to be completed in an effective manner. In addition, the cart must allow flexibility for an expanded role in the Deposit Recovery Program. The desired cart features required to meet these objectives are outlined below.

- Capability for initial evacuation of air from a $400 \mathrm{ft}^{3}$ volume to $\sim 0.02$ psia (allows for large contingency).

- Gas manifold for charging $\mathrm{ClF}_{3}$ (26 lb max.), $\mathrm{F}_{2}$ (1.0 lb max.), $\mathrm{N}_{2}(10 \mathrm{scf}$ ), dry air (plant header). Figures allow for large contingency. The equipment must allow $\mathrm{ClF}_{3}$ to be accurately charged to an evacuated vessel to a range of pressures from 0.25 psia to 7 psia.

- Two sets of $\mathrm{NaF}$ traps for selective removal of $\mathrm{UF}_{6}(22.0 \mathrm{lb})$ and $\mathrm{HF}(3.7 \mathrm{lb})$ from the gas streain. One set temperature controlled to $200^{\circ} \mathrm{F}$ for $\mathrm{UF}_{6}$ removal and one set at ambient temperature for $\mathrm{HF}$ removal. The $\mathrm{NaF}$ traps used to trap $\mathrm{UF}_{6}$ will be regenerated.

- Capability to accommodate both series and parallel flow through the two sets of NaF traps.

- Ability to circulate the process gases from the item being decontaminated through the $\mathrm{NaF}$ traps and back to the decontamination item.

- Capability to connect with a Fourier Transform Infrared Spectrometer for gas analysis at the points indicated in Figure 2.

- System for recovery of the $\mathrm{UF}_{6}$ from the NaF traps. The $\mathrm{UF}_{6}$ recovery system will require a refrigeration unit with either a $5 \mathrm{~A}$ or $5 \mathrm{~B}$ cylinder $(55 \mathrm{lb}$ capacity) to freeze out $\mathrm{UF}_{6}$, and a method for flowing a mixture of $\mathrm{F}_{2}$ and $\mathrm{N}_{2}$ in the direction opposite normal flow through the $\mathrm{NaF}$ traps while heating the traps to $700^{\circ} \mathrm{F}$.

- Portable tank of $\sim 280 \mathrm{ft}^{3}$ capacity for collecting the off-gases for transportation to the KOH scrubber.

- KOH scrubber system for removing the excess $\mathrm{ClF}_{3}$ and other by-product gases (designed for removal at $\sim 2.3 \mathrm{lb} / \mathrm{h}$ of $\mathrm{ClF}_{3}$ ) from the process off-gases prior to venting the gases out a stack.

- Ability to carefully regulate flow of the gases to the KOH scrubber to avoid excessive heating.

- Ability to dilute the $\mathrm{ClF}_{3}$ in the off-gases with dry air to $<5 \%$ vol to avoid overheating the KOH scrubber.

- Five-inch critically safe geometry for all pipes, NaF traps, cold trap cylinders, gas sampling pump (P3), etc. to the maximum extent possible.

- Air jet and stack connection for final removal of the off-gas effluent from the scrubber.

- Pressure regulated dry air flow controller to allow dry air to be supplied to a vessel at a range of pressures from 0.5 psia to 14.7 psia.

- Subatmospheric operation of all decontamination process equipment. 


\subsection{MATERIAL BALANCE SUMMARY}

The largest item requiring treatment during the deposit recovery program is a size 1 converter which has a void volume of $\sim 200 \mathrm{ft}^{3}$. (A decision was made to recover the uranium deposits from the $1300 \mathrm{ft}^{3}$ surge tanks using mechanical methods rather than with gas-phase treatments). The $200 \mathrm{ft}^{3}$ volume base case was increased by $100 \%$ to $400 \mathrm{ft}^{3}$ to allow a large design contingency. The $\mathrm{ClF}_{3}$ will be charged to the $400 \mathrm{ft}^{3}$ volume to a pressure of 4 psia at $75^{\circ} \mathrm{F}$, which amounts to $25.8 \mathrm{lb}^{-} \mathrm{ClF}_{3}$. An assumption was made that $50 \%$ of the $\mathrm{ClF}_{3}$ will be consumed in a reaction with a $14.2 \mathrm{lb}$ deposit of $\mathrm{UO}_{2} F_{2}(10.9 \mathrm{lb} \mathrm{U})$ within the $400 \mathrm{ft}^{3}$ volume. The off-gases from this reaction, which is described by Equation 5, are summarized in Table 1.

Table 1. Approximate gas composition at the end of the decontamination process

\begin{tabular}{|c|c|c|c|c|c|}
\hline $\begin{array}{l}\text { Off-gases from } \\
\text { the item } \\
\text { decon'd }\end{array}$ & Mass (lb) & Mol. wt. & Moles (lb) & Moles \% & $\begin{array}{l}\text { Partial pressures } \\
\text { (psia) }\end{array}$ \\
\hline $\mathrm{ClF}_{3}$ & 13.0 & 92.4 & 0.140 & 33.5 & 2.00 \\
\hline $\mathrm{UF}_{6}$ & 16.2 & 352.0 & 0.046 & 11.0 & 0.66 \\
\hline $\mathrm{ClO}_{2} \mathrm{~F}$ & 6.0 & 86.4 & 0.070 & 16.7 & 1.00 \\
\hline $\mathrm{ClF}$ & 3.8 & 54.4 & 0.070 & 16.8 & 1.00 \\
\hline $\mathrm{HF}$ & 1.8 & 20.0 & 0.092 & 22.0 & 1.32 \\
\hline Total & 40.8 & & 0.418 & 100.0 & 5.58 \\
\hline
\end{tabular}

Following removal of the $\mathrm{UF}_{6}$ and $\mathrm{HF}$ from the off-gases by use of the NaF traps as described in detail in the next section, the gas composition will be that shown in Table 2. These figures represent an estimate of the composition and amounts of the off-gases that would be disposed in a $\mathrm{KOH}$ scrubber.

Table 2. Approximate gas composition following removal of $\mathrm{UF}_{6}$ and $\mathrm{HF}$

\begin{tabular}{|c|c|c|c|c|c|}
\hline $\begin{array}{l}\text { Off-gases from } \\
\text { the item decon'd }\end{array}$ & Mass (lb) & Mol. wt. & Moles (lb) & Moles \% & $\begin{array}{c}\text { Partial pressures } \\
\text { (psia) }\end{array}$ \\
\hline $\mathrm{ClF}_{3}$ & 13.0 & 92.4 & 0.14 & 50.0 & 2.0 \\
\hline $\mathrm{ClO}_{2} \mathrm{~F}$ & 6.0 & 86.4 & 0.07 & 25.0 & 1.0 \\
\hline $\mathrm{ClF}$ & 3.8 & 54.4 & 0.07 & 25.0 & 1.0 \\
\hline Total & 22.8 & & 0.24 & 100.0 & 4.0 \\
\hline
\end{tabular}

The above gas compositions are at best rough approximations because the amount of uranium in each item will vary. Also, items of different volumes will be encountered. The upper limit on the amount of fluorinating gases requiring disposal would result if no $\mathrm{UO}_{2} \mathrm{~F}_{2}$ 
were present for reaction with $\mathrm{ClF}_{3}$. In this case, $\sim 25.8 \mathrm{lb}$ of $\mathrm{ClF}_{3}$ would require disposal. This amount represents the maximum theoretical load to a $\mathrm{KOH}$ scrubber.

An air supply will be required at the item being decontaminated and at the $\mathrm{KOH}$ scrubber. Less than $400 \mathrm{scf}$ of dry air will be required to conduct the purge and evacuation cycles that rid the decontaminated item of toxic gases at the conclusion of the process. (These cycles are described in the next section). This air may be supplied through the plant air header if the equipment is located near a header; otherwise, bottled air could be used. An air header is presently located in the area where the $\mathrm{KOH}$ scrubber will be situated in the K-27 Building. The off-gases will be evacuated from the portable tank to the $\mathrm{KOH}$ scrubber at a rate of 10 $\mathrm{scfm}$. These gases would have a maximum worst-case concentration of $100 \% \mathrm{ClF}_{3}$. Since the concentration of $\mathrm{ClF}_{3}$ should not exceed $5 \%$ as it enters the scrubber, an air flow rate of $\sim 190 \mathrm{scfm}$ will be required to dilute the off-gases at a location upstream of the scrubber.

Supporting calculations and other technical design details are contained in Appendix B. The process flow diagrams, which describe all process streams, have been completed and are contained in Appendix C. During the engineering design, the piping and instrument drawings and specifications will be completed, which will detail the design package.

\subsection{EQUIPMENT OPERATION}

Figure 2 is a schematic of the equipment necessary to meet the project objectives. This schematic is intended to be detailed enough to illustrate the concept of how the equipment would be used, but it is not intended to show design details such as instrumentation and interlocks. Pump P1 shown in Figure 2 will be used for the initial evacuation of the air from the contaminated diffusion equipment, for the recirculation of process gases when desired to remove $\mathrm{UF}_{6}$ and $\mathrm{HF}$, and for the evacuation of the process gases into the portable tank. Several pump candidates have been identified for this application that have the required operating characteristics and that can be used for $\mathrm{ClF}_{3}$ service. An Ebara rotary lobe pump with nickel coated interior and $\mathrm{N}_{2}$ purged seal cavities, a Normetex spiral diaphragm pump, and multihead metal bellows pumps run in parallel are possible choices that are being evaluated. A NaF trap bypass line is shown in Figure 2 to allow the air initially present in the item to be evacuated without pumping it through the NaF traps. The by-pass is desirable to keep moisture from the air out of the $\mathrm{NaF}$. If permissible from an industrial hygiene viewpoint, the air from the initial evacuation will be released into the building interior after passing through an alumina trap (not shown in Figure 2), which would remove residues of $\mathrm{UF}_{6}$ and $\mathrm{HF}$ that may remain from the gaseous diffusion operation decades ago.

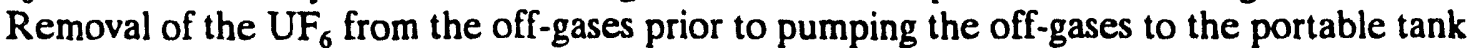
is desirable for the reasons given in Section 3. The equipment described in Figure 2 will allow the gas to be circulated out of the decontamination item through valves 11 and 12 , through the $\mathrm{NaF}$ traps, and back to the decontamination item via pump P1 through valves 30,9 , and 10.

The two sets of $\mathrm{NaF}$ traps will allow a series gas flow arrangement through the sets, and each set is arranged to allow parallel flow through the two traps contained in the set. The first set of traps will be maintained at $\sim 200^{\circ} \mathrm{F}$ ("hot NaF") to selectively trap $\mathrm{UF}_{6}$ while allowing HF to pass through. (Two five-foot long, five-inch ID traps will trap $>22 \mathrm{lb} \mathrm{UF}_{6}$ ). The second set of traps will be maintained at ambient temperature ("ambient $\mathrm{NaF}^{\mathrm{N}}$ ) to trap $\mathrm{HF}$ and residual amounts of $\mathrm{UF}_{6}$. The recommended flow rate for trapping $\mathrm{UF}_{6}$ in a single five-inch diameter trap is $8.2 \mathrm{cfm}$ (see Appendix B). 


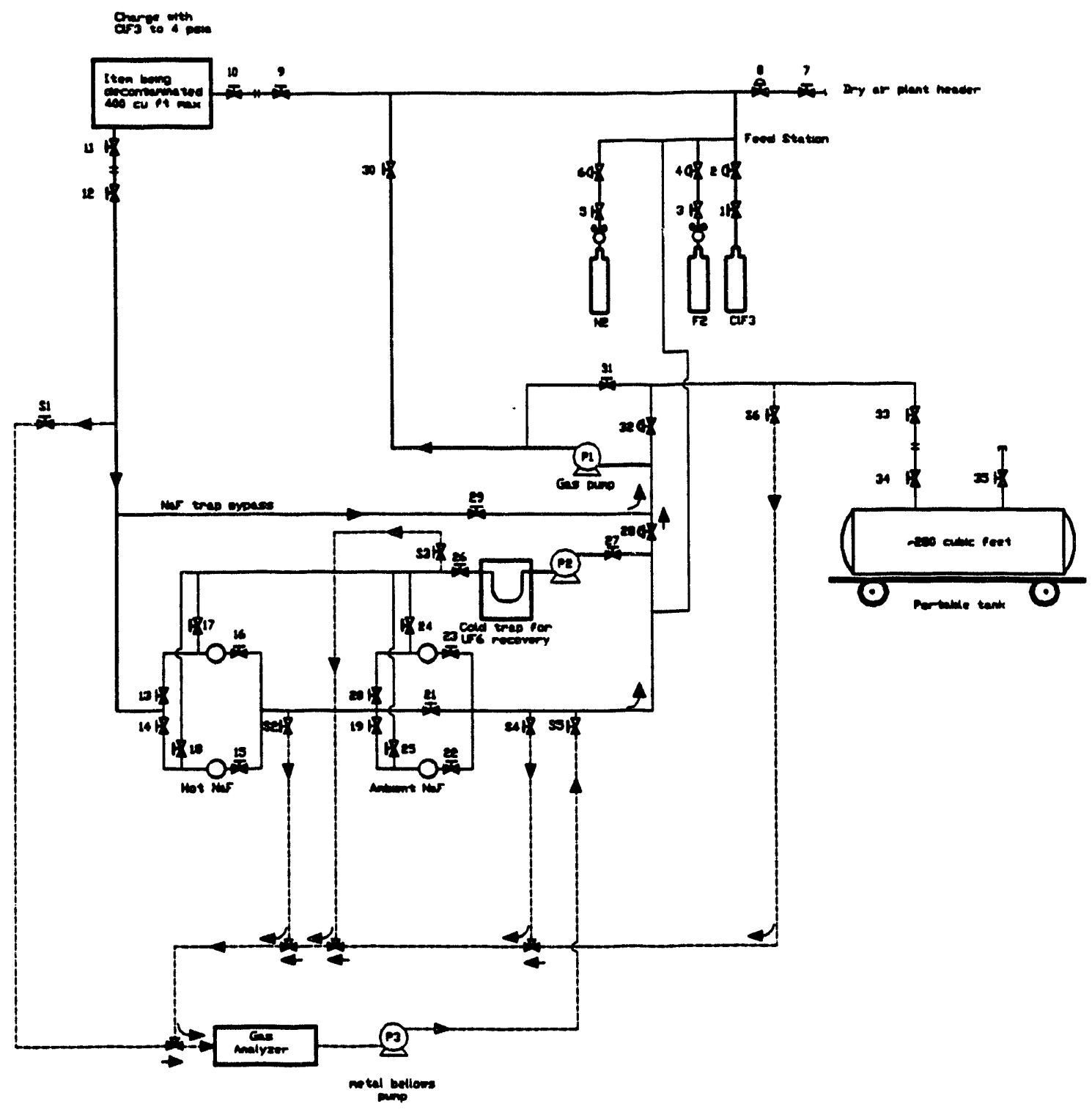

Fig. 2. Schematic of gas-phase decontamination demonstration equipment. 
When removal of the $\mathrm{UF}_{6}$ from the process gases is desired, the gases will first be flowed in the recirculating loop through the hot $\mathrm{NaF}$ traps (with the ambient $\mathrm{NaF}$ traps valved out) and back into the decontaminated item until the flow rate through the $\mathrm{NaF}$ traps is properly adjusted with control valve 28 to ensure the $U F_{6}$ is being adequately removed to low levels. The ambient $\mathrm{NaF}$ traps will be valved out initially to minimize the accumulation of $\mathrm{UF}_{6}$ in the ambient $\mathrm{NaF}$ traps. For this arrangement, the following $\mathrm{NaF}$ station valves will be open (valves $13,14,15,16,21$ ) and the following $\mathrm{NaF}$ station valves will be closed (valves 17,18 , $19,20,22,23,24,25,26$, and 27$)$. The $\mathrm{UF}_{6}$ concentration will be monitored at a point after the hot NaF traps by use of a FTIR. When the UF 6 concentration is confirmed at low levels (perhaps $<30 \mathrm{ppm}$ ), the ambient $\mathrm{NaF}$ set will be valved in a series arrangement with the hot NaF sct by opening the following valves 19, 20, 22, and 23 and closing valve 21 .

The arrangement just described can be used with the recirculating loop described earlier to selectively remove the $\mathrm{UF}_{6}$ and $\mathrm{HF}$ from the process gases for the purpose of continuing the reaction of the $\mathrm{ClF}_{3}$ with an unusually large uranium deposit (makeup $\mathrm{ClF}_{3}$ could be added while removing the $\mathrm{UF}_{6}$ and $\mathrm{HF}$ ), or this arrangement can be used in preparation for evacuation of the process gases from the decontaminated item into the portable tank at the conclusion of a treatment. To evacuate the gases, valves 31,33 , and 34 to the portable tank will be opened and valve 30 located in the line back to the decontaminated item will be closed. The gases from the decontaminated item will be evacuated to less than 0.02 psia via the same pump used to recirculate the gases, P1. Following evacuation of the gases to 0.02 psia, dry air vill be added and evacuated from the decontaminated item several times to reduce the residual gases to a concentration of less than one part per million.

Table 3 contains an illustration of how these evacuation and dilution cycles may be used to reduce the residual gas concentrations to $0.4 \mathrm{ppm}$ by pumping the gases and the diluent air from a decontaminated item of $400 \mathrm{ft}^{3}$ volume to a portable tank of $280 \mathrm{ft}^{3}$ volume. The " $E$ " in Table 3 represents an evacuation of gases from the decontaminated item. Initially the item is assumed to contain gases at a pressure of 6 psia. The composition of the gases will be roughly that shown in Table 2 ; but as a simplification, the gas mixture will be assumed as a pure gas (that is, initially at a concentration of $1,000,000 \mathrm{ppm}$ ). The gas is assumed to be evacuated to a pressure of 0.02 psia during each evacuation cycle, except during the last evacuation cycle shown it is evacuated only to 0.1 psia since this is sufficient to obtain the desired dilution upon increasing the pressure to 14.7 psia with air. The " $\mathrm{D}$ " in the table represents a dilution step in which dry air is added to the item to dilute the remaining gas prior to the next evacuation. In this example, air is added until the pressure reaches 0.5 psia, which dilutes the residual gas by a factor of 25 . A range of pressures could have been chosen for the air dilution step, but the choice is not totally random. If a higher pressure is used, a higher dilution factor will result per step, but more air will be used to obtain an equivalent dilution of the gas, which would result in filling the portable tank faster. Minimizing the amount of diluent air is desirable to avoid having to empty the portable tank before finishing the evacuation and dilution operation. Note that the total gas pressure in the portable tank resulting from the evacuation cycles in this illustration is less than 10.5 psia, well below atmospheric pressure. 
Table 3. Off-gas evacuation and dilution cycles

\begin{tabular}{ll|c|c|c}
\hline $\begin{array}{c}\text { Gas evacuation from } 400 \mathrm{ft}^{3} \\
\text { decontaminated item } \\
\text { (psia) }\end{array}$ & $\begin{array}{c}\text { Dilution } \\
\text { factor }\end{array}$ & $\begin{array}{c}\text { Gas conc in } \\
\text { decontaminated } \\
\text { item (ppm) }\end{array}$ & $\begin{array}{c}\text { Resulting pressure in } \\
280 \mathrm{ft}^{3} \text { portable tank } \\
\text { (psia) }\end{array}$ \\
\hline $\mathrm{E}^{1} 6.0$ & -0.02 & - & $1,000,000$ & 8.5 \\
$\mathrm{D}^{2} 0.02$ & -0.5 & 25 & 40,000 & 8.5 \\
$\mathrm{E} 0.5$ & -0.02 & - & 40,000 & 9.2 \\
$\mathrm{D} 0.02$ & -0.5 & 25 & 1,600 & 9.2 \\
$\mathrm{E} 0.5$ & -0.02 & - & 1,600 & 9.9 \\
$\mathrm{D} 0.02$ & -0.5 & 25 & 64 & 9.9 \\
$\mathrm{E} 0.5$ & -0.1 & -0.5 & 10.5 \\
$\mathrm{D}^{3} 0.1$ & -14.7 & 147 & 0.4 & 10.5 \\
\hline
\end{tabular}

1. The pressure of the off-gases in the $400 \mathrm{ft}^{3}$ decontaminated item is assumed to initially be 6.0 psia. The pressure is evacuated (E) to 0.02 psia and the evacuated gases are pumped into the $280 \mathrm{ft}^{3}$ portable tank.

2. The residual gases in the decontaminated item are diluted (D) by adding dry air to increase the pressure to 0.5 psia.

3. Venting the evacuated item to atmospheric pressure completes the dilution of the original off-gases to $0.4 \mathrm{ppm}$.

Since the $\mathrm{ClF}_{3}$ is charged in excess into the item being decontaminated, the off-gases from one decontamination operation could be used as part of the charge gases for the next operation following removal of the $\mathrm{UF}_{6}$ and HF. Reusing the gases would minimize scrubber wastes as well as conserve $\mathrm{ClF}_{3}$. (Eventually the buildup of $\mathrm{ClO}_{2} \mathrm{~F}$ and $\mathrm{ClF}$ will require disposal of the off-gases but better utilization of the $\mathrm{ClF}_{3}$ can be realized reusing the gases as long as possible). The equipment shown in Figure 2 will allow the gases to be pumped from the portable tank into the item requiring decontamination (assuming the decontamination item was previously evacuated) by closing valve 31 and opening valves $30,32,33$, and 34 . Of course, if the off-gases are to be reused, they would not be diluted with air as described above.

The equipment illustrated in Figure 2 will allow parallel as well as series flow through the two sets of $\mathrm{NaF}$ traps. Parallel flow is always undesirable when significant amounts of $\mathrm{UF}_{6}$ are present in the gases, since collecting the $\mathrm{UF}_{6}$ exclusively in the hot $\mathrm{NaF}$ is desirable. However, the concentrations of $\mathrm{UF}_{6}, \mathrm{HF}$, and fluorinating gases will be slight after the first evacuation of the process gases to 0.02 psia. At this point, the flow rate through the $\mathrm{NaF}$ traps could be doubled by switching from series flow to parallel flow through the hot $\mathrm{NaF}$ and ambient $\mathrm{NaF}$ sets. To make the switch from series to parallel flow, the following valves would be closed (19 and 20$)$ and the following would be opened $(17,18,21,24$, and 25$)$.

When the NaF becomes fully loaded with $\mathrm{UF}_{6}$, the $\mathrm{UF}_{6}$ can be recovered from the NaF by heating the $\mathrm{NaF}$ traps to $\sim 700^{\circ} \mathrm{F}$ while flowing a stream of nitrogen and $\mathrm{F}_{2}$ gas through the traps in the opposite direction of normal gas flow. The $U^{F_{6}}$ will then be purged from the $\mathrm{NaF}$ traps into the refrigeration unit, where it will be frozen out into a 5-inch M5A or M5B $\mathrm{UF}_{6}$ cylinder. $\mathrm{UF}_{6}$ will be recovered only from the hot $\mathrm{NaF}$ set because transferring the HF contained in the ambient $\mathrm{NaF}$ set to the $\mathrm{UF}_{6}$ freezeout cylinders is undesirable. This process can be accomplished by closing valves $13,14,19,20,22,23$, and 28 and opening valves 15 , $16,17,18,21,26$, and $27 . F_{2}$ and $N_{2}$ will be administered into the flow loop as desired via 
flow control valves 4 and 6 until the desired concentration of $F_{2}(3 \%)$ is obtained. A metal bellows pump, P2, will be used to circulate the gases through the $\mathrm{NaF}$ traps and the refrigeration unit in a closed loop arrangement.

The off-gases contained in the portable tank will be disposed in a $\mathrm{KOH}$ scrubber 'ncated at the K-27 building. The K-27 building is already equipped with a suitable stack and a work area for a scrubber. A scrubber which was built and placed into service shortly before the shutdown of the gaseous diffusion cascade is still located in K-27, but it is far oversized for the present project. Preliminary contacts with vendors who have previously built scrubbers for the disposal of $\mathrm{ClF}_{3}$ indicate that a small scrubber suitable for the project may be purchased for less than the cost of reactivating the present scrubber. Figure 3 is a simplified schematic of the connection of the portable tank to the $\mathrm{KOH}$ scrubber. The gases will be pumped from the tank through a control valve that will control the flow rate of the gas. Dry air will be added to reduce the concentration of the fluorinating gases to less than $5 \%$ upstream of the scrubber. The scrubber will remove the fluorine and chlorine constituents of the off-gases very effectively as described in section 1.3 , and the cleansed gases (mainly air) will be vented out the stack. The portable tank will be evacuated to less than 0.02 psia in preparation for its next use. 


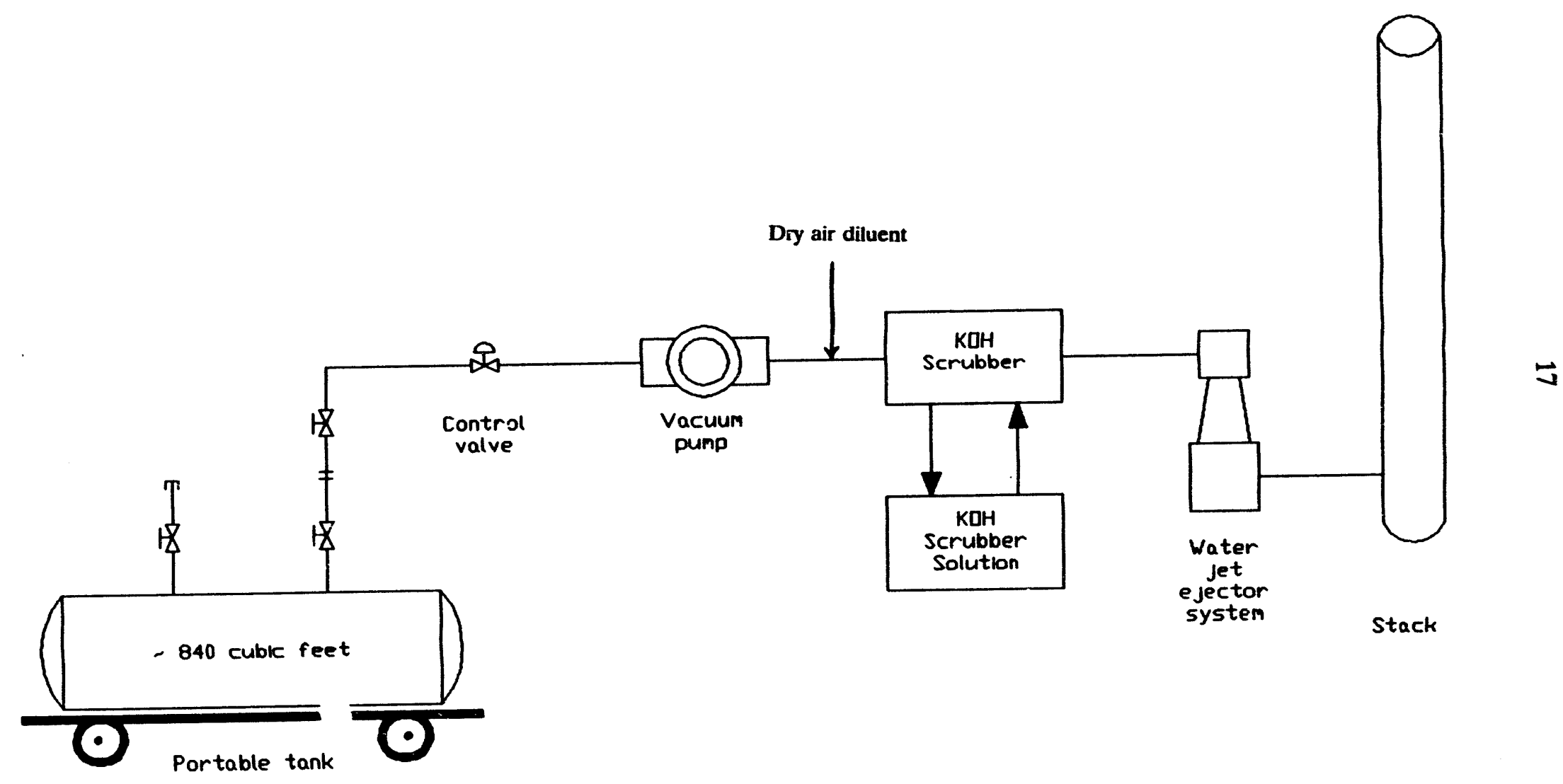

Fig. 3. Schematic of gas disposal system. 


\section{CONCLUSIONS}

The preconceptual design of the gas-phase decontamination demonstration equipment has been completed, which will serve as the starting point for the engineering des.gn. This equipment will allow the process steps to be conducted in an effective manner. The equipment based on this design will be suitable for special applications beyond the initial demonstration. Assisting the Deposit Recovery Program in removing uranium deposits from selected items of gaseous diffusion equipment in the K-25 building may be one special application. Since a size 1 converter with a void volume of $\sim 200 \mathrm{ft}^{3}$ is the largest volume of interest for gas-phase decontamination in the Deposit Recovery Program, a $200 \mathrm{ft}^{3}$ volume has been chosen as a base figure for the design. A design contingency of $100 \%$ has been added to the base figure to allow flexibility of the equipment for special projects, therefore, a maximum volume of $400 \mathrm{ft}^{3}$ has been assumed for the largest item to be decontaminated.

The two NaF traps that are intended to trap $\mathrm{UF}_{6}$ at $200^{\circ} \mathrm{F}$ are capable of trapping $>22$ $\mathrm{lb}$ of $\mathrm{UF}_{6}$ without being regenerated. These traps are followed by two additional NaF traps which will be operated at ambient temperatures to trap HF. These HF traps will also serve to backup the UF ${ }_{6}$ traps. When the $\mathrm{UF}_{6}$ traps are fully loaded, they will be regenerated by heating them to $-700^{\circ} \mathrm{F}$ and purging out the $\mathrm{UF}_{6}$ into a freezeout cylinder. The proposed equipment design will allow the amount of $\mathrm{UF}_{6}$ in the off-gases to be reduced to very low levels as confirmed by analysis with a FTIR gas analyzer before the gases are pumped into a portable tank for transport to a $\mathrm{KOH}$ scrubber for disposal. The entire system will be maintained at subatmospheric pressure. 


\section{REFERENCES}

1. E. B. Munday and D. W. Simmons, Feasibility of Gas-Phase Decontamination of Gaseous Diffusion Equipment, K/TCD-1048, Martin Marietta Energy Systems, Oak Ridge K-25 Site, February 1993.

2. R. C. Shrewsberry and E. L. Williamson, "Chemistry of the Chlorine Trifluoride Uranyl Fluoride Reaction," Joumal of Inorganic Nuclear Chemistry 28, 2535-2539 (1966).

3. T. D. Cooper, F. N. Dost, and C. H. Wang, "Evidence for ClOF as a Primary Product of the Reaction of $\mathrm{ClF}_{3}$ with $\mathrm{H}_{2} \mathrm{O}$," Joumal of Inorganic Nuclear Chemistry 28, 3564-3567 (1972).

4. R. L. Farrar, Jr., Safe Handling of Chlorine Trifluoride and the Chemistry of the Chlorine Oxides and Oxyfluorides, K-1416, Union Carbide Corporation Nuclear Division, Oak Ridge Gaseous Diffusion Plant, November 1960.

5. R. L. Farrar, Jr. and E. J. Barber, Some Considerations in the Handling of Fluorine and the Chlorine Fluorides, K/ET-252, Union Carbide Corporation Nuclear Division, Oak Ridge Gaseous Diffusion Plant, July 1979.

6. S. Katz, "Use of High-Surface Area Sodium Fluoride to Prepare $\mathrm{MF}_{6} \bullet 2 \mathrm{NaF}$ Complex with Uranium, Tungsten, and Molybdenum Hexafluorides," Inorganic Chemistry 3, 1598-1600 (1964).

7. A. J. Saraceno, unpublished data, May 1987.

8. R. M. Schultz, W. E. Hobbs, J. L. Norton, and M. J. Stephenson, Sorbent Selection and Design Considerations for Uranium Trapping, K/ET-5025, Union Carbide Nuclear Division, Oak Ridge Gaseous Diffusion Plant, July 1981.

9. R. S. Eby, Union Carbide Nuclear Division, Oak Ridge Gaseous Diffusion Plant, personal communication to L. L. Parris, Union Carbide Corporation Nuclear Division, Oak Ridge Gaseous Diffusion Plant, July, 1980.

10. A. J. Story and R. W. Perkins, unpublished data, January 1981.

11. P. G. Brown, Martin Marietta Energy Systems, Inc., Paducah Gaseous Diffusion Plant, personal communication to E. B. Munday, Martin Marietta Energy Systems, Inc., Oak Ridge K-25 Site, July 1993.

12. A. J. Saraceno, N. F. Reiter, M. J. Orlett, and J. T. Hicks, Disposal of Halogen Containing Gas Emissions at the Portsmouth Plant Site, GAT-T-2784, Goodyear Atomic Corporation, Portsmouth Gaseous Diffusion Plant, December 1978. 
13. N. F. Reiter and A. J. Saraceno, Effects of Halogen Chemicals on KOH Scrubber Solution, GAT-521-78-55, Interdepart - 1ental Correspondence, Goodyear Atomic Corporation, Portsmouth Gaseous Diffusion Plant, March 1978.

14. P. Welesko and D. H. Bunch, Performance and Capabilities of the Purge Cascade Trapping' and Scrubber Systems, K/PS-1075, Martin Marietta Energy Systems, Oak Ridge K-25 Site, April 1985.

15. E. J. Barber, Martin Marietta Energy Systems, Inc., Oak Ridge K-25 Site, personal communication to E. B. Munday, Martin Marietta Energy Systems, Oak Ridge K-25 Site, October 1993.

16. D. H. Bunch, Martin Marietta Energy Systems, Inc., K-25 Site, personal communication to E. B. Munday, Martin Marietta Energy Systems, Inc., K-25 Site, September 1993.

17. E. B. Munday, Chloroflourocarbon Leak Detection Technology, K/QT-390, Martin Marietta Energy Systems, Inc., Oak Ridge K-25 Site, December 1990. 
Appendix A

COST ESTIMATE FOR DISPOSAL OF CHLORINE TRIFLUORIDE IN A POTASSIUM HYDROXIDE SCRUBBER 


\title{
A-2
}

Appendix A

\section{COST ESTIMATE FOR DISPOSAL OF CHIORINE TRIFLUORIDE IN A POTASSIUM HYDROXIDE SCRUBBER}

\begin{abstract}
As described in the main body of the report, the KF constituent of the waste $\mathrm{KOH}$ solution can be regenerated to $\mathrm{KOH}$ by addition of $\mathrm{Ca}(\mathrm{OH})_{2}$. This method for regeneration of the waste $\mathrm{KOH}$ solution would likely be used during a full-production decontamination campaign; however, for the demonstration, the regeneration step is not practical for the relatively small amounts of waste solution generated. For the demonstration, the waste solutions would probably be neutralized with $\mathrm{HCl}$ and then calcium chloride would be added to precipitate calcium fluoride $\left(\mathrm{CaF}_{2}\right)$. The $\mathrm{CaF}_{2}$ precipitate is the main solid waste resulting from the process. The costs for the chemical processing requirement for disposal of the waste solution without regeneration and the cost for $\mathrm{CaF}$ sludge disposal were estimated by personnel at the K-25 Site at $\$ 11.77$ per pound of $\mathrm{ClF}_{3}$ costs disposal. (These costs are summarized below). These costs do not include any allowance for the initial equipment construction or scrubber operation. Since environmental requirements have changed greatly since this process was last used at the K-25 Site, modifications to this method would be required that would likely increase the costs considerably if the process were to be implemented today.
\end{abstract}

\section{POUNDS OF KOH NEEDED}

$\mathrm{ClF}_{3}+4 \mathrm{KOH}-3 \mathrm{KF}+1 / 3 \mathrm{KCl}+2 \mathrm{H}_{2} \mathrm{O}+2 / 3 \mathrm{KClO}_{3}$

One mole of $\mathrm{ClF}_{3}$ consumes four moles of $\mathrm{KOH}$.

\section{If All of the KOH Were Used,}

$$
\text { lb of } \mathrm{KOH}=\frac{4 \text { moles } \mathrm{KOH}}{1 \text { mole } \mathrm{ClF}_{3}} \times \frac{1 \text { mole } \mathrm{ClF}_{3}}{92.45 \mathrm{lb} \mathrm{ClF}} \times \frac{56.09 \mathrm{lb} \mathrm{KOH}}{1 \text { mole } \mathrm{KOH}}=2.42 \frac{\mathrm{lb} \mathrm{KOH}}{l b \mathrm{ClF}_{3}}
$$

The scrubber is initially filled with $20 \% \mathrm{KOH}$ solution. This is used until the concentration falls to $10 \% \mathrm{KOH}$. The solution is then replaced. Therefore, only half of the $\mathrm{KOH}$ is used and the other half is wasted.

$$
\text { lb of } \mathrm{KOH}=\frac{2.42 \mathrm{lb} \mathrm{KOH} \text { reacted }}{1 \mathrm{lb} \mathrm{ClF}} \times \frac{2 \mathrm{lb} \mathrm{KOH}}{l b \mathrm{KOH} \text { reacted }}=4.84 \frac{l b \mathrm{KOH}}{l b C l F_{3}}
$$




\section{COST OF THE KOH SOLUTION}

$\mathrm{KOH}$ solution is $90 \% \mathrm{KOH}$ and costs $\$ 0.75 / \mathrm{b}$ solution.

$$
\begin{aligned}
& \text { Cost per lb of } \mathrm{ClF}_{3}=\frac{4.84 \mathrm{lb} \mathrm{KOH}}{\mathrm{lb} \mathrm{ClF} F_{3}} \times \frac{\$ 0.75}{l b \text { solution }} \times \frac{1 \mathrm{lb} \text { solution }}{0.9 \mathrm{lb} \mathrm{KOH}} \\
& =\$ 4.04 / \mathrm{lb} C l F_{3}
\end{aligned}
$$

\section{POUNDS OF WASTE SCRUBBER SOLUTION GENERATED}

For every pound of $\mathrm{KOH}$ reacted, one pound of $\mathrm{KOH}$ is wasted. Since the concentration of the waste solution is $10 \% \mathrm{KOH}, 10$ pounds of waste solution are generated per $\mathrm{lb}$ of $\mathrm{KOH}$ reacted.

$$
\begin{aligned}
\text { Pounds of waste scrubber solution } & =\frac{2.42 \mathrm{lb} \text { of } \mathrm{KOH} \text { reacted }}{\mathrm{lb} \mathrm{ClF}} \times \frac{10 \mathrm{lb} \text { solution }}{l b \mathrm{KOH} \text { reacted }} \\
& =24.2 \mathrm{lb} \text { waste solution } / \mathrm{lb} \mathrm{ClF_{3 }}
\end{aligned}
$$

\section{CALCULATION OF WASTE SCRUBBER SOLUTION DENSITY}

For every 100lb of initial $\mathrm{KOH}$ solution, there are $20 \mathrm{lb}$ of $\mathrm{KOH}$ of which $10 \mathrm{lb}$ reacts with $\mathrm{ClF}_{3}$. Therefore, per 100lb of initial $\mathrm{KOH}$ solution, the following amounts of products will be generated per the indicated equation.

$$
\mathrm{ClF}_{3}+4 \mathrm{KOH}-3 \mathrm{KF}+1 / 3 \mathrm{KCl}+2 \mathrm{H}_{2} \mathrm{O}+2 / 3 \mathrm{KClO}_{3}
$$

\begin{tabular}{lcccccc}
\hline & $\mathrm{CIF}_{3}$ & $\mathrm{KOH}$ & $\mathrm{KF}$ & $\mathrm{KCl}$ & $\mathrm{H}_{2} \mathrm{O}$ & $\mathrm{KClO}_{3}$ \\
\hline Mol w. & 92.4 & 56.0 & 58.1 & 74.6 & 18.0 & 122.5 \\
Mass (lb) & 4.06 & 10.00 & 7.67 & 1.12 & 1.58 & 3.68 \\
Moles & 0.044 & 0.178 & 0.132 & 0.015 & 0.088 & 0.030 \\
$\begin{array}{l}\text { Density } \\
\text { (lb/gal) }\end{array}$ & & 17.06 & 20.70 & 16.59 & 8.34 & 19.51 \\
\hline
\end{tabular}

From the above figures, the total weight of the resulting solution following reaction with $\mathrm{ClF}_{3}$ can be summarized as follows: 


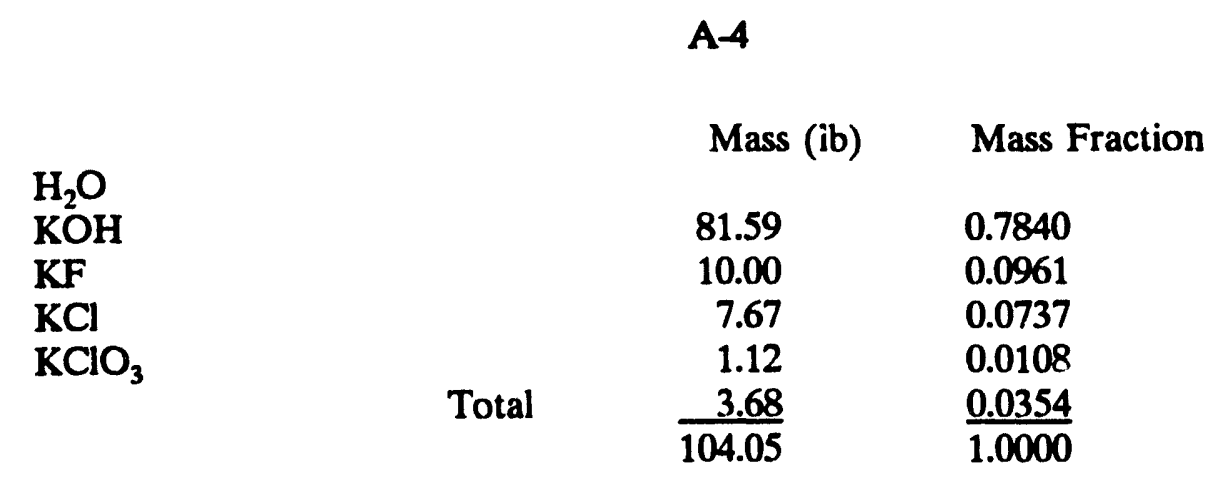

Assuming one pound of an ideal solution, the following specific volume of the solution can be calculated.

$$
\begin{aligned}
\text { Volume }=\frac{0.7840 \mathrm{lb} \mathrm{H} \mathrm{H}_{2} \mathrm{O}}{8.34 \mathrm{lb} / \mathrm{gal}}+\frac{0.0961 \mathrm{lb} \mathrm{KOH}}{17.06 \mathrm{lb} / \mathrm{gal}}+\frac{0.0737 \mathrm{lb} \mathrm{KF}}{20.70 \mathrm{lb} / \mathrm{gal}}+\frac{0.0108 \mathrm{lb} \mathrm{KCl}}{16.59 \mathrm{lb} / \mathrm{gal}} \\
+\frac{0.0354 \mathrm{lb} \mathrm{KClO}}{19.51 \mathrm{lb} / \mathrm{gal}} \\
\text { Volume }=0.1057 \mathrm{gal} \text { for one pound of the solution. } \\
\text { Specific volume }=0.1057 \mathrm{galllb} \\
\text { Density }=9.46 \mathrm{lb} / \mathrm{gal}
\end{aligned}
$$

\section{GALLONS OF WASTE SCRUBBER SOLUTION GENERATED}

Assume density of solution $=9.46 \mathrm{lb} / \mathrm{gal}$

$$
\text { Gallons of waste scrubber solution }=\frac{24.2 \mathrm{lb} \frac{\text { waste solution }}{l b C l F_{3}}}{9.46 \frac{l b}{\text { gallon }}}=\frac{2.56 \text { gal waste solution }}{l b C l F_{3}}
$$

\section{COST TO PROCESS THE KOH WASTES SOLUTION}

According to G. D. Conner(4/14/89), cost to process $\mathrm{KOH}$ waste solution $=\$ 1.20 /$ gallon.

$$
C \text { ast }=\frac{2.56 \mathrm{gal} \text { waste solution }}{l b C l F_{3}} \times \frac{\$ 1.20}{\text { gal waste solution }}=\$ 3.07 / l b C l F_{3}
$$




\section{A-5}

POUNDS OF $\mathrm{CaF}_{2}$ GENERATED

$\mathrm{ClF}_{3}+4 \mathrm{KOH}-3 \mathrm{KF}+1 / 3 \mathrm{KCl}+2 \mathrm{H}_{2} \mathrm{O}+2 / 3 \mathrm{KClO}_{3}$

$3 \mathrm{KF}+11 / 2 \mathrm{CaCl}_{2}-11 / 2 \mathrm{CaF}_{2} \downarrow+3 \mathrm{KCl}$

One mole of $\mathrm{ClF}_{3}$ results in $11 / 2$ moles of $\mathrm{CaF}_{2}$.

$$
\begin{aligned}
& \text { lb of } \mathrm{CaF}_{2}=\frac{1 \frac{1}{2} \text { moles } \mathrm{CaF}_{2}}{\text { moles } \mathrm{ClF}_{3}} \times \frac{1 \text { mole } \mathrm{ClF}_{3}}{92.45 \mathrm{bbClF}} \times \frac{78.08 \mathrm{lb} \mathrm{CaF}}{1 \text { mole CaF }} \\
& =1.27 \text { lb CaF } / l b \mathrm{ClF}_{3}
\end{aligned}
$$

\section{POUNDS OF SLUDGE GENERATED}

Assume the sludge would be about $60 \%$ solids. This assumption is based on previous sludge density figures following centrifugation of the sludge.

$$
\text { Pounds of sludge }=\frac{1.27 \frac{\mathrm{lb} \mathrm{CaF_{2 }}}{l b C l F_{3}}}{0.6 \frac{\mathrm{lb} \mathrm{CaF_{2 }}}{l b \text { sludge }}}=2.11 \mathrm{lb} \text { sludge/lb } \mathrm{ClF}
$$

\section{SPECIFIC VOLUME OF SLUDGE}

Assume an ideal solution.

$$
P_{\mathrm{CaP}_{2}}=3.18 \mathrm{~g} / \mathrm{ml}=26.52 \mathrm{lb} / \mathrm{gal}
$$

$$
\rho_{\mathrm{H}_{2} \mathrm{O}}=8.34 \mathrm{lb} / \mathrm{gal}
$$

$1 \mathrm{lb}$ sludge $=0.6 \mathrm{lb} \mathrm{CaF_{2 }}+0.4 \mathrm{lb} \mathrm{H}_{2} \mathrm{O}$ 


$$
\text { Specific Volume }=\frac{0.6 l b \mathrm{CaF}_{2}}{26.52 \frac{l b}{g a l}}+\frac{0.4 l b \mathrm{H}_{2} \mathrm{O}}{8.34 \frac{l b}{8 a l}}=0.0706 \mathrm{gall} l \mathrm{~b}
$$

\section{VOLUME OF SLUDGE GENERATED}

$$
\text { Sludge generated }=2.11 \frac{l b \text { sludge }}{l b C l F_{3}} \times 0.0706 \frac{\text { gal sludge }}{l b \text { sludge }}=0.149 \text { gal sludge } / b C L F_{3}
$$

\section{COST OF SLUDGE DISPOSAL}

According to J. L. Shoemaker (2/19/93), it is going to cost $\$ 50$ million to dispose of 32,000 drums (1.6 million gallons) of pond sludge. This estimate may not be strictly applicable to the $\mathrm{KOH}$ sludge, but it is the best basis for approximation at present.

$$
\text { Cost per gallon }=\frac{\$ 50,000,000}{1,600,000 \text { gal }}=\$ 31.2 / \text { gal }
$$

Cost per $l b$ of $C l F_{3}=0.149 \frac{g a l \text { sludge }}{l b C l F_{3}} \times \frac{\$ 31.25}{\text { gal sludge }}=\$ 4.66 / l b C l F_{3}$

\section{SUMMARY OF COSTS TO DISPOSE OF 1 POUND OF $\mathrm{CF}_{3}$}

Cost of $\mathrm{KOH}$

Cost to treat waste solution

Cost to dispose of sludge
$\$ 4.04$

$\$ 3.07$

$\$ 4.66$ 
Appendix B

GAS-PHASE DESIGN INFORMATION 
B-2

Appendix B

\section{GAS-PHASE DESIGN INFORMATION}

\section{MAXIMUM CFF 3 CHARGED}

Corresponds to a $200 \mathrm{ft}^{3}$ size 1 converter charged to 4 psia with $\mathrm{ClF}_{3}$ at $75^{\circ} \mathrm{F}$.

$$
\begin{aligned}
& M(\text { mass })=\text { mol. wt. } \times \text { moles }=92.4(\text { PV } / R T) \text {; } \\
& \mathrm{R}=10.73 \mathrm{psia} \bullet \mathrm{ft}^{3} /\left(\mathrm{lb} \text { mole } \bullet{ }^{\circ} \mathrm{R}\right) \\
& M=92.4[(4 \times 200) /(10.73 \times 535)]=92.4(0.139) \\
& \mathrm{M}=12.9 \mathrm{lb} \mathrm{ClF}_{3}
\end{aligned}
$$

The above figure of $12.9 \mathrm{lb}$ of $\mathrm{ClF}_{3}$ will be doubled to $25.8 \mathrm{Ib} \mathrm{ClF}_{3}$ to allow for a large design contingency.

Any gas at $1 \mathrm{psia}, 75^{\circ} \mathrm{F}$ in a $200 \mathrm{ft}^{3}$ volume will consist of the following number of moles moles $=0.139 / 4=0.0348$ moles $/$ psia (at $75^{\circ} \mathrm{F}$ in $200 \mathrm{ft}^{3}$ volume)

$\mathrm{CF}_{3}-\mathrm{UO}_{2} \mathrm{~F}_{2}$ EQUATION (BASE CASE FOR A SIZE 1 CONVERTER WITH A VOID VOLUME OF $200 \mathrm{ft}^{3}$ )

$$
3 \mathrm{CF}_{3}+\mathrm{UO}_{2} \mathrm{~F}_{2} \cdot \mathrm{H}_{2} \mathrm{O} \rightarrow 1.5 \mathrm{CO}_{2} \mathrm{~F}+1.5 \mathrm{CF}+\mathrm{UF}_{6}+2 \mathrm{HF}
$$

Assume that half of the $\mathrm{ClF}_{3}$ contained in a size 1 converter reacts with uranium in the form of $\mathrm{UO}_{2} \mathrm{~F}_{2} \bullet \mathrm{H}_{2} \mathrm{O}$. This assumption is equivalent to assuming that $\sim 6.4 \mathrm{lb}$ of the initial 12.9 $\mathrm{lb} \mathrm{ClF}_{3}$ present in the converter reacts with $7.1 \mathrm{lb}$ of $\mathrm{UO}_{2} \mathrm{~F}_{2}(5.49 \mathrm{lb} \mathrm{U})$ leaving an excess of $6.5 \mathrm{lb}$ of $\mathrm{ClF}_{3}$. An excess of $\mathrm{ClF}_{3}$ is desirable for increased reaction rate and to avoid the generation of $\mathrm{ClO}_{2}$ as a reaction by-product.

\begin{tabular}{llllllll}
\hline & $\mathrm{CFF}_{3}$ & $\mathrm{UO}_{2} \mathrm{~F}_{2}$ & $\mathrm{H}_{2} \mathrm{O}$ & $\mathrm{CO}_{2} \mathrm{~F}$ & $\mathrm{CF}$ & $\mathrm{UF}_{6}$ & $\mathrm{HF}$ \\
\hline Mol wt & 92.4 & 308 & 18 & 86.4 & 54.4 & 352.0 & 20.0 \\
Mass (lbs) & 6.5 & 7.1 & 0.41 & 3.0 & 1.9 & 8.1 & 0.92 \\
Lb moles & 0.07 & 0.023 & 0.023 & 0.035 & 0.035 & 0.023 & 0.046 \\
\hline
\end{tabular}

In Table 2 located in the body of this report, the above figures were doubled to allow a large design contingency.

\section{CHEMICAL TRAP INFORMATION}

Assume 5-in-ID critically safe traps for highly enriched uranium (HEU) service.

Volume per foot of 5-in-ID trap $=\pi(5 / 2)^{2} \times 12$ in $=235.6 \mathrm{in}^{3} / \mathrm{ft}\left(0.136 \mathrm{ft}^{3} / \mathrm{ft}\right)$. 
Bulk density of $\mathrm{NaF}^{\mathrm{B} 1}: 65 \mathrm{lb} / \mathrm{ft}^{3}$

Amount of NaF trapping agent per foot of 5-in-ID trap:

$\left(65 \mathrm{lb} / \mathrm{ft}^{3}\right)\left(0.136 \mathrm{ft}^{3} / \mathrm{ft}\right)=8.84 \mathrm{lb} / \mathrm{ft}$

Recommended design loading of $\mathrm{UF}_{6}$ on $\mathrm{NaF}$ expressed as a weight percent of NaF: $25 \%^{\mathrm{Bt}}$

Amount of $\mathrm{UF}_{6}$ that can be trapped in two 5-in-ID traps that are five-feet long:

$2 \times 5 \mathrm{ft} \times 8.84 \mathrm{lb} \mathrm{NaF} / \mathrm{ft} \times 0.25 \mathrm{lb} \mathrm{UF}_{6}$ per lb NaF $=22.1 \mathrm{lb} \mathrm{UF_{6 }}(14.9 \mathrm{lb} \mathrm{U})$

This capacity is much more than enough in the majority of cases. If greater capacity is needed, the traps will be regenerated.

Recommended face velocity for gas-flow in NaF traps (reference pressure near atmospheric pressure):

\section{$1.0 \mathrm{ft} / \mathrm{s}$ (near room temperature) ${ }^{\mathrm{B1}}$}

Flow rate through traps based on recommended face velocities (5-in traps):

$$
\text { Area }=\pi r^{2}=\pi(2.5)^{2}=19.6 \mathrm{in}^{2}\left(0.1361 \mathrm{ft}^{2}\right)
$$

Cfm for one 5-in-ID NaF trap: $(1 \mathrm{ft} / \mathrm{s})\left(0.1361 \mathrm{ft}^{2}\right)(60 \mathrm{~s} / \mathrm{m})=8.17 \mathrm{cfm} \mathrm{NaF} \mathrm{trap}$

\section{TRAP PRESSURE DROP ${ }^{B 1}$}

$$
\frac{\Delta P}{L}=C_{1} \mu U_{m}+C_{2} \rho_{m} U_{m}^{2}
$$

where $\Delta \mathbf{P}=$ pressure drop (torr)

$\mathrm{L}=$ height of bed ( $\mathrm{ft}$ )

$\mathrm{C}_{1}=54.4$ (for $1 / 8$ inch right circular cylindrical pellets of $\mathrm{NaF}$ )

$C_{2}=14.9$ (for $1 / 8$ inch right circular cylindrical pellets of NaF)

$\mu=$ fluid viscosity (cP)

$U_{m}=$ superficial fluid velocity based on an empty vessel (fps)

$\rho_{\mathrm{m}}=$ mean fluid density $\left(\mathrm{lb} / \mathrm{ft}^{3}\right)$

The above data are the results of the tests that were made over a pressure range of 0.5 to 750 torr at ambient temperature and with an average superficial velocity of 0.05 to $4 \mathrm{fps}$. As an illustration of the above equation, assume the following:

$$
\begin{aligned}
& \mathrm{L}=5 \mathrm{ft} \\
& \mu=0.022 \mathrm{cP} \\
& \mathrm{U}_{\mathrm{m}}=1.0 \mathrm{fps}
\end{aligned}
$$


$\rho_{\mathrm{w}}=0.101 \mathrm{lb} / \mathrm{ft}^{3}$ (calculated by assuming the product gases shown in Table 3 located Then in the report body are ideal).

$$
\begin{aligned}
& \Delta P=5\left(54.4 \times 0.022 \times 1.0+14.9 \times 0.101 \times 1.0^{2}\right) \\
& \Delta P=13.5 \text { torr }
\end{aligned}
$$

\section{GAS CYLINDER CAPACTTIES}

$\mathrm{ClF}_{3}$ available in $160 \mathrm{lb}$ cylinders (6.8 psig @70 $\mathrm{F}$ ).

$\mathrm{F}_{2}$ available in $4.9 \mathrm{lb}$ per cylinder $\left(400 \mathrm{psig} @ 70^{\circ} \mathrm{F}\right)$.

$\mathrm{N}_{2}$ available in 360 scf cylinders $\left(2000\right.$ psig @ $70^{\circ} \mathrm{F}$ ). May also be available in plant header. A plant air header runs through the K-25 building. Repairs may be needed at locations of interest in the building.

\section{VISCOSITY OF COMPOUNDS OF INTEREST AT 1 ATM PRESSURE}

The viscosity is not expected to vary significantly at lower pressures. Viscosity values will be needed during the engineering detailed design to calculate pressure drops in the piping and equipment.

The following viscosity values were selected from the indicated sources (highest temperature available was included). All data is expressed in centipoise (cP) units.

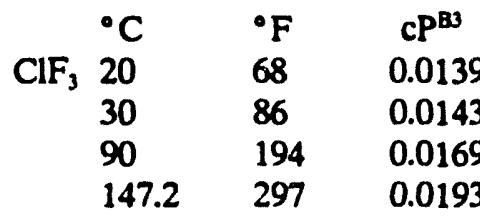

$\begin{array}{clll} & { }^{\circ} \mathrm{C} & { }^{\circ} \mathrm{F} & \mathrm{CP}^{83} \\ \mathrm{ClF} & 20 & 68 & 0.0171 \\ & 30 & 86 & 0.0176 \\ & 90 & 194 & 0.0206\end{array}$

$\begin{array}{clc}{ }^{\circ} \mathrm{C} & { }^{\circ} \mathrm{F} & \mathrm{CP}^{\mathrm{B} 3} \\ \mathrm{ClO}_{3} \mathrm{~F}{ }_{20} & 68 & 0.0141 \\ 30 & 86 & 0.0146 \\ 90 & 194 & 0.0172 \\ 150 & 302 & 0.0197\end{array}$




\section{B.5}

-

$\begin{array}{rll}\text { UF }_{6} & { }^{\circ} \mathrm{C} & \cdot{ }^{\circ} \mathrm{F} \\ & 30 & 68 \\ 84.9 & 86 \\ 90 & 194 \\ & 200 & 392 \\ 263 & 505\end{array}$

$\mathrm{CP}^{\mathrm{B} 3}$

0.0170

0.0175

0.0240

$94 \quad 0.0205$

0.0261

0.0322

$\begin{array}{llll}\bullet \mathrm{C} & { }^{\circ} \mathrm{F} & \mathrm{CP}^{\mathrm{B3}} \\ & 20 & 68 & 0.0126 \\ 30 & 80 & 0.0130 \\ & 90 & 194 & 0.0156 \\ 150 & 302 & 0.0183\end{array}$

\begin{tabular}{|c|c|c|c|}
\hline${ }^{\circ} \mathrm{C}$ & ${ }^{\circ} \mathrm{F}$ & $\mathrm{CP}^{\mathrm{BJ}}$ & $\mathrm{CP}^{\mathrm{BS}}$ \\
\hline 20 & 68 & 0.0239 & 0.0222 \\
\hline 26.7 & 80 & & 0.0228 \\
\hline 30 & 86 & 0.0245 & \\
\hline 90 & 194 & 0.0279 & \\
\hline 93.3 & 200 & & 0.2900 \\
\hline 343.3 & 650 & & 0.0530 \\
\hline 371 & 700 & & 0.0560 \\
\hline
\end{tabular}

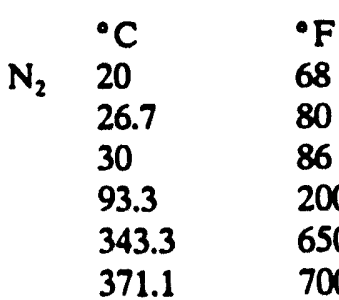

$\mathrm{CP}^{\mathrm{BS}}$

0.0174

0.0177

0.0178

0.0205

0.0302

0.0312

$\begin{array}{lllr} & { }^{\circ} \mathrm{C} & { }^{\circ} \mathrm{F} & \mathrm{cP} \\ \mathrm{O}_{2} & 20 & 68 & 0.0200 \\ & 26.7 & 80 & 0.0203 \\ & 93.3 & 200 & 0.0234 \\ & 343.3 & 650 & 0.0335 \\ & 371.1 & 700 & 0.0340 \\ & & & \\ & & & \\ & { }^{\circ} \mathrm{C} & { }^{\mathrm{O}} \mathrm{F} & \mathrm{CP} \\ \text { Air } & 20 & 68 & 0.0177 \\ & 26.7 & 80 & 0.0180 \\ & 93.3 & 200 & 0.0208 \\ & 343.3 & 650 & 0.0295 \\ & 371.1 & 700 & 0.0305\end{array}$




\section{VISCOSITY VALUE ESTIMATES FOR GAS MIXTURES FOR USE IN THE PROCESS FLOW DIAGRAMS}

The effect of pressure on gas viscosity is not significant up to pressures of $\sim 10$ atmospheres ${ }^{\mathrm{BS}}$. The viscosity of a gas mixture is seldom a linear function of composition, and the viscosity of a mixture can exceed the viscosity of either component by a factor usually less than $30 \%^{\mathrm{B}}$.

(1) Estimate of off-gas mixture viscosity at $-80^{\circ} \mathrm{F}$ : The off-gas mixture will contain the following constituents: $\mathrm{ClF}_{3}, \mathrm{UF}_{6}, \mathrm{ClO}_{2} \mathrm{~F}, \mathrm{ClF}, \mathrm{HF}$.

From the viscosity data for these compounds we see that the viscosity varies from a low of about $0.0130 \mathrm{cP}$ for HF to a high of $\sim 0.0176 \mathrm{cP}$ for $\mathrm{ClF}$, which is not greatly different. Since the mixture viscosity can exceed the component viscosity, the viscosity of CIF will be multiplied by 1.3 as a conservative estimate for the mixture viscosity.

$$
\begin{gathered}
\text { Mixture viscosity }-0.0176 \times 1.3 \\
\sim 0.022 \mathrm{cP}
\end{gathered}
$$

(2) Estimate for the $\mathrm{N}_{2}-\mathrm{F}_{2}$ mixture used during regeneration of the $\mathrm{NaF}$ traps at $700^{\circ} \mathrm{F}$ : The $\mathrm{N}_{2}-\mathrm{F}_{2}$ mixture is only $3 \% \mathrm{~F}_{2}$ and contains only a small percentage of $U F_{6}$; therefore, the viscosity will be approximated as that of pure $\mathrm{N}_{2}$ at $700^{\circ} \mathrm{F}$.

Viscosity of $\mathrm{N}_{2}-\mathrm{F}_{2}$ mixture at $700^{\circ} \mathrm{F} \sim 0.0312 \mathrm{cP}$

(3) Estimate for the initial air evacuation and air dilution and evacuation cycles: The viscosity is that of air at $80^{\circ} \mathrm{F}$.

Viscosity of air at $80^{\circ} \mathrm{F}=0.0180 \mathrm{cP}$ 


\section{B-7}

Appendix B

\section{REFERENCES}

B1.R. M. Schultz, W. E. Hobbs, J. L. Norton, and M. J. Stephenson, Sorbent Selection and Design Considerations for Uranium Trapping, K/ET-5025, Union Carbide Nuclear Division, Oak Ridge Gaseous Diffusion Plant, July 1981.

${ }^{B 2}$ M. G. Otey and C. K. Bayne, Fixed Bed Trapping for Gaseous Fluoride Effluent Control, KY-705, Union Carbide Corporation Nuclear Division, Paducah Gaseous Diffusion Plant, Paducah, Kentucky, June 1980.

B3.Jean Ostorero, Mesure de la Viscosite de Quelques Gaz Fluores, CEA-N-1293, Centre d'Etudes Nucleaires de Saclay, Commissariat a l'Energie Atomique, France, April 1970.

${ }^{B 4}$. R. DeWitt, Uranium Hexafluoride: A Survey of the Physico-Chemical Properties, GAT280, Goodyear Atomic Corporation, Portsmouth, Ohio, August 1960.

${ }^{B S}$.R. H. Perry and C. H. Chilton, Chemical Engineer's Handbook, 5th Ed., McGraw-Hill Book Company, New York, 1973.

B6.R. C. Reid, J. M. Prausnitz, and T. K. Sherwood, The Properties of Gases and Liquids, 3rd Ed., McGraw-Hill Book Company, New York, 1977. 
Appendix C

PROCESS FLOW DIAGRAMS 


\section{Oak Ridge K-25 STIE}

\section{W. D. Altman}

H. L. Bailey, Jr.

E. J. Barber

C. E. Benson (ORNL)

W. D. Bostick

N. P. Brady

D. H. Bunch

R. D. Bundy (2)

T. W. Burwinkle (ORNL)

F. P. Delozier

R. S. Eby

D. E. Fain

R. L. Fellows

J. I. Frazier

J. M. Googin (Y-12)

H. H. Haselton

L. C. Hensley

R. L Higgins

G. J. Hornyak

J. M. Kennerly

R. K. Kibbe

L. D. Ladd

A. C. Lay

D. Lyles

A. P. Malinauskas

E. B. Munday (10)

D. W. Neiswander (2)

J. H. Pashley

F. S. Patton

G. A. Person

D. A. Poole

B. E. Prince

A. S. Quist (3)*

R. L. Ritter

D. W. Simmons (2)

D. B. Smith

L. D. Trowbridge

Applied Technology Library

K-25 Plant Records

\section{Department Of Energy-Headquarters}

T. D. Anderson

C. W. Frank

K. E. Hain

J. M. Hyde

J. L. Kelly

J. M. Lankford

W. E. Murphy

L. H. Taylor

H. Thron

R. P. Whitfield

Department of Enerey - Oak Ridge

M. R. Jugan

R. Korynta

J. O. Moore

E. J. Powell

F. P. Riddle

R. C. Sleeman

\section{PORTSMOUTH}

J. G. Crawford

A. J. Saraceno

R. T. Shelton

Portsmouth Gaseous Diffusion Plant Library

PGDP

PGDP Library

- Two copies to the Office of Scientfic and Technical Information. 


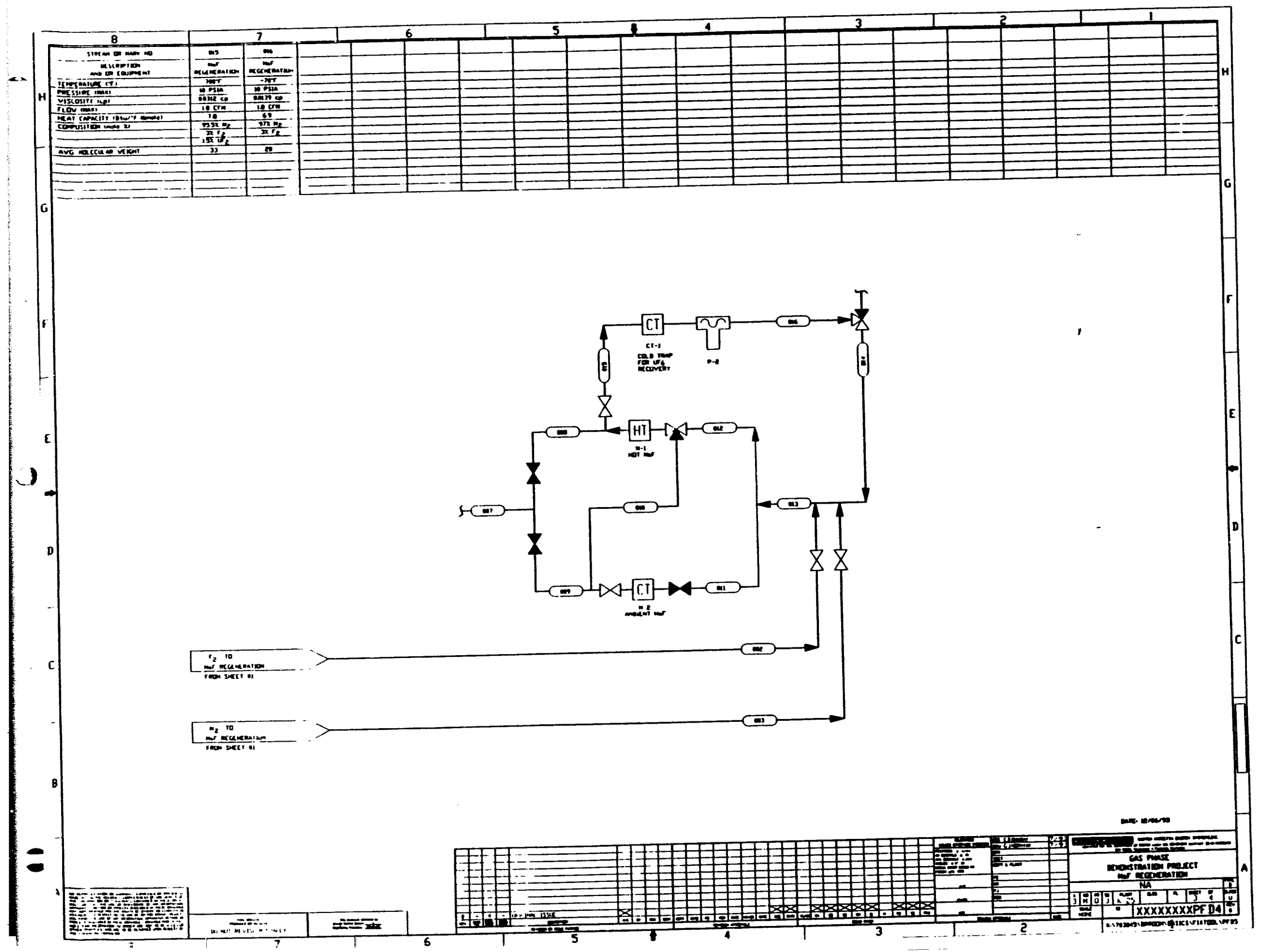




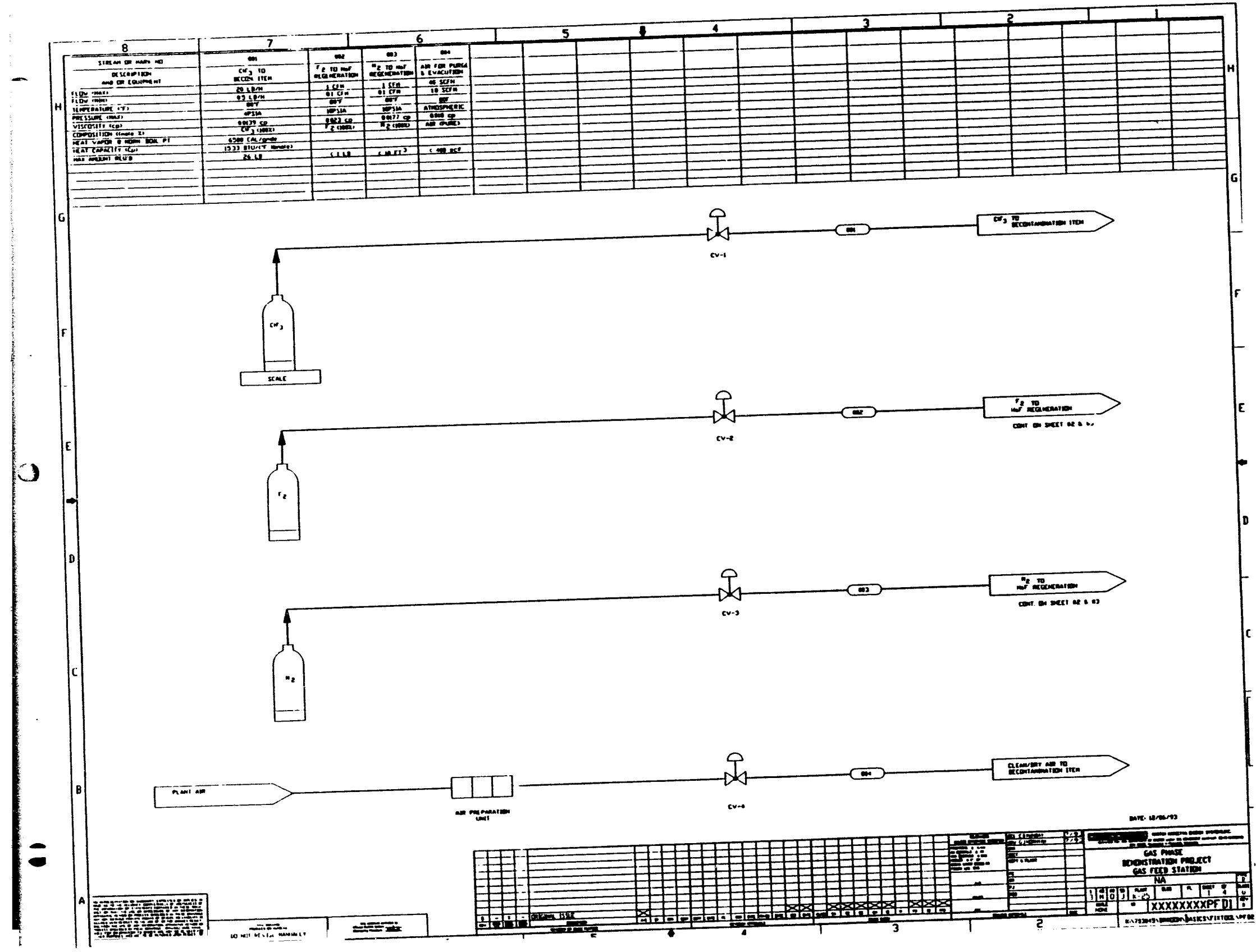




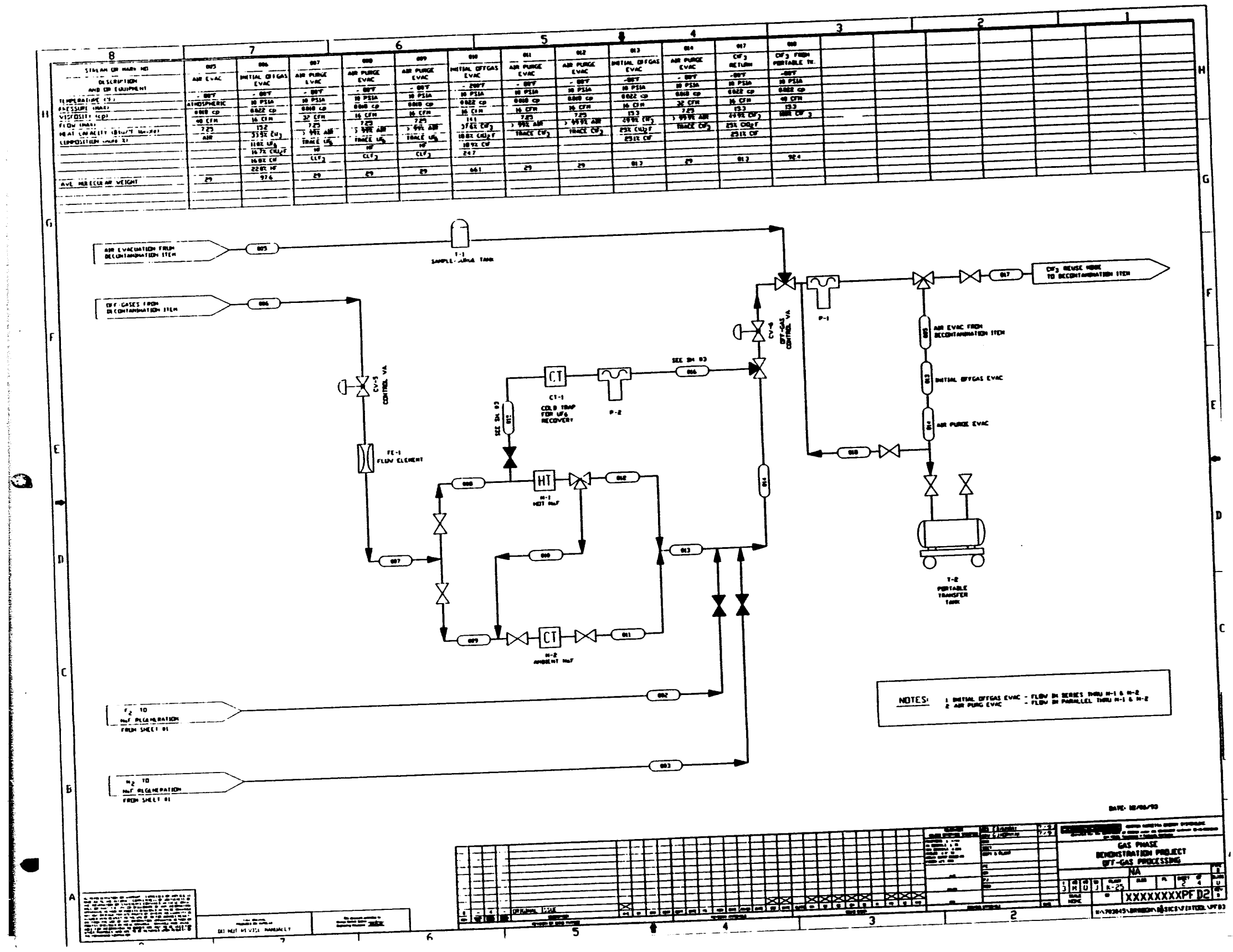

